NBER WORKING PAPER SERIES

\title{
POISEDNESS AND PROPAGATION: \\ ORGANIZATIONAL EMERGENCE AND THE TRANSFORMATION OF CIVIC ORDER IN 19TH-CENTURY NEW YORK CITY
}

\author{
Victoria Johnson \\ Walter W. Powell \\ Working Paper 21011 \\ http://www.nber.org/papers/w21011 \\ NATIONAL BUREAU OF ECONOMIC RESEARCH \\ 1050 Massachusetts Avenue \\ Cambridge, MA 02138 \\ March 2015
}

We are very grateful to Rebecca Sunde for exceptional research assistance. We have benefited from comments from the participants in seminars at the University of Mannheim, the Wirtschaftsuniversität Wien, the University of Cambridge, the National Bureau of Economic Research's Economic History Workshop, and the Economic Sociology and Networks and Organizations workshops at Stanford, as well as from Howard Aldrich, Tim Bartley, Julie Battilana, Christof Brandtner, Patricia Bromley, Joon Nak Choi, Nitsan Chorev, Jeannette Colyvas, Avinash Dixit, Mark Granovetter, Mauro Guillén, Ira Katznelson, Naomi Lamoreaux, Margaret Levi, Jonathan Levy, Mark Mizruchi, Chandra Mukerji, Wanda Orlikowski, Jason Owen-Smith, and Charles Perrow. The views expressed herein are those of the authors and do not necessarily reflect the views of the National Bureau of Economic Research.

NBER working papers are circulated for discussion and comment purposes. They have not been peerreviewed or been subject to the review by the NBER Board of Directors that accompanies official NBER publications.

(C) 2015 by Victoria Johnson and Walter W. Powell. All rights reserved. Short sections of text, not to exceed two paragraphs, may be quoted without explicit permission provided that full credit, including (C) notice, is given to the source. 
Poisedness and Propagation: Organizational Emergence and the Transformation of Civic Order in 19th-Century New York City

Victoria Johnson and Walter W. Powell

NBER Working Paper No. 21011

March 2015

JEL No. N11,N5

\begin{abstract}
$\underline{\text { ABSTRACT }}$
The emergence of novelty, especially of new categories of people and organizations, is undertheorized in the social sciences. Some social worlds are more hospitable to novel introductions or exogenous perturbations than others. Explaining this relative "poisedness" is essential to understanding when and why new organizational forms appear, persist, and expand, both cognitively and geographically. We offer a comparative analysis of two cases of emergence in 19th-century New York City that examines the conditions under which a new organizational form-a research-intensive botanical garden - developed and took root. We show that social worlds are highly poised when environmental, intellectual, and civic factors have reinforcing consequences. Poisedness is amplified when the social character of the individuals produced by specific historical milieux attunes these innovators to the larger social and material processes that favor the creation of new modes of organization. Although our analysis of poisedness is fixed on a specific time and place, New York City over the course of the 19th century, our arguments about the emergence of new organizational forms apply readily to other settings and time periods.
\end{abstract}

Victoria Johnson

University of Michigan

vjohnsn@umich.edu

Walter W. Powell

Stanford University

woodyp@stanford.edu 


\section{INTRODUCTION}

When and why do new kinds of organizations emerge, persist, and spread? Some settings are more hospitable to novelty or exogenous perturbations than are others. We think explaining this relative social "poisedness" is essential to understanding when and why new organizational forms appear and take root. By poisedness, we mean the availability or vulnerability of a social and historical context to the reception of an innovation and subsequent reconfiguration by it (Padgett and Powell 2012, pp. 26-28). ${ }^{1}$ Poisedness thus refers to circumstances that are rich with potential, in which relations and trends at one level are available to be coupled with innovations at a different one. When such coupling occurs, the second level becomes a self-sustaining pool for these innovations. In turn, the fates of the two become intertwined and have cascading effects. The changes that ensue alter the nature of what is accessible, introducing new possibilities. The resulting inter-related pathways through social and economic structures afford the opportunity for novelty through unanticipated feedbacks across multiple contexts.

How do we analyze the architecture of social structures to understand which ones are more fertile for new forms of organization? Because "organizational genesis does not mean virgin birth" (Padgett and Powell 2012, p. 2), studying social poisedness requires situating innovators and their organizational projects with regard to the structural features of the social world into which they are introduced. Our approach emphasizes that historical development is an evolving, multi-level process in which new interests and new persons are catalyzed, and the criteria for accomplishment emerge out of this open-ended process.

\footnotetext{
${ }^{1}$ Our use of the term "poisedness" has provoked mixed reactions among readers, with several recoiling from it as unfamiliar jargon and others appreciating its dynamism. Several colleagues have suggested more familiar terms, such as "receptivity" or "amenable to." But we find these lacking. Poisedness conveys potential readiness for action, be it availability or vulnerability. The concept is a familiar one in mathematics and optimization research, where it refers to the geometry of an underlying interpolation set, and whether such estimates are easy or difficult constraints (Conn, Scheinberg, and Vicente 2005). It has also been used in philosophy in reference to changes in states of consciousness (Tye 2000). In contemporary evolutionary biology (Wagner 2005), a kindred term is evolvability, describing an environmental setting that is available for transformation.
} 
The emergence of novelty, especially of new categories of people and organizations, is undertheorized in the social sciences. To be sure, there are hints at answers to these puzzles in a variety of subfields. Exogenous shocks are a familiar explanation: Social upheavals, technological disruptions, and regulatory change can disturb the status quo and signal opportunities for new practices and new organizations. In such circumstances we often find differential selection, as new entrants replace established ones (Hannan and Freeman 1977; Arthur 1994). But selection by itself is limiting, not generative. A similar line of explanation unfolding at a different level of analysis argues that people on the periphery of a field, and thus less beholden to its practices, are more likely to initiate change (Leblebici et al. 1991; Schneiberg 2007). Other explanations stress complexity, conflict, and plurality, suggesting that those in contradictory positions are most able to initiate change (Thelen 2004). And another productive line of work calls attention to "critical junctures," or periods of contingency when the usual constraints on action are lifted or eased (Katznelson 2003).

Thus, whether the focus is on exogenous shocks, periphery-core dynamics, contradictory locations, or critical junctures, most explanations do not take into account the interlocking of individual human lives with large-scale social, cultural, political, and material changes. Historical sociologists have argued that time is lumpy, unpredictable, and discontinuous (Abbott 2001). Such a view alerts us, as Sewell (2005, p. 10) notes, "that the consequences of a given act are not intrinsic in the act but rather will depend on the nature of the social world within which it takes place." Temporal heterogeneity renders some actions incomprehensible or illegitimate at certain historical moments, yet easily comprehensible and legitimate at others.

In recent years, historically minded social scientists have demonstrated that comparative and longitudinal approaches throw into relief the shared as well as distinct characteristics of the social structures under investigation, thereby aiding in more accurate causal explanations and in the specification of scope conditions (Mahoney 2010; Mahoney and Thelen 2010). We believe these 
methods offer powerful tools for explaining why some social contexts appear poised to support the emergence of particular organizational forms and others do not. To this end, we compare two examples from 19th-century urban history that might at first glance seem small and local but are in fact deeply connected to important processes, events, and figures of their day. We chose our cases, each of which concerns an effort to introduce a research-focused botanical garden in New York City, for their similar beginnings and divergent outcomes. We use these rich cases, set against the backdrop of New York's transformation from a port town of 60,000 into a world city of nearly two million, to build arguments about how the success with which skillful individuals shepherd new organizational forms into their social worlds, and subsequently transform them, is powerfully shaped by the structural potentials present in those milieux.

We demonstrate the availability of a specific time and place (New York City near the end of the 19th century) to a novel organizational form (a research-intensive botanical garden) proposed by an engaged, entrepreneurial man of science, whose very presence was rendered possible by developments in the profession of American science. Our claim is not merely that history and context matter, but that particular organizational models have resonance depending on their ability to couple with identifiable material, intellectual, and political-economic circumstances and connect with changes in the larger organizational landscape. Social poisedness, we argue, affords opportunities for new organizational forms to arise.

Our choice of cases emerged out of a broader inquiry into the history and organization of botany and botanical gardens in the United States. One of the most important botanical gardens in the world today, the New York Botanical Garden (NYBG), was founded in the Gilded Age through a collaboration of leading American industrialists with politicians and academic botanists. However, this institution was preceded by a similar garden founded ninety years earlier, when much of Manhattan was covered with farms and country estates. As we studied these cases side by side, we found striking 
parallels in the two founders' efforts and visions, coupled with a stark divergence in the respective outcomes. $^{2}$

Our founders, David Hosack (1769-1835) and Nathaniel Britton (1859-1934), each recognized an opportunity to transform American botany. Separated by nearly a century, their projects show remarkable similarities that make them a rich pairing through which to explore the emergence of a new organizational form. Hosack was a Columbia professor of botany recently returned from Great Britain when he began, in the 1790s, to dream of establishing a botanical garden on Manhattan Island that would advance American botany, medicine, and agriculture. Winning the support of such eminent figures as Hamilton and Jefferson, he spent the next decade establishing the nation's most extensive botanical garden. Using private funds, he amassed more than 2000 plant specimens and began to teach botany and medicine. Hosack's garden collapsed fifteen years later, because he could not muster state or private funding, and the model he introduced - a research- and teaching-based botanical garden, spawned no imitators. Today, his garden is buried under Rockefeller Center.

In the late 1880s, Nathaniel Britton, also a Columbia professor of botany who had recently returned from travels to England, began to imagine creating a botanical garden that would advance American botany, medicine, and agriculture. Supported by contemporary colossi such as Carnegie and Rockefeller, he spent the next decade establishing a garden in New York City on a physical and scientific scale unrivaled in the United States. Today, the NYBG still thrives on 250 acres in the Bronx. What is more, soon after its creation in the 1890s, it spawned imitators in cities across the country. Thus Britton

\footnotetext{
${ }^{2}$ Primary research on these two organizational cases was conducted over two years, partly in the context of research for a book by Victoria Johnson on David Hosack and the Elgin Botanic Garden (forthcoming from Bloomsbury Press). We consulted materials in the following archives: the American Philosophical Society; Columbia University (Manuscripts and Rare Books Division; the Special Collections of the College of Physicians \& Surgeons); the Historical Society of Pennsylvania; the Library of Congress; the Mertz Library of the New York Botanical Garden; the New York Academy of Medicine; the New-York Historical Society; the New York Public Library (Lionel Pincus and Princess Firyal Map Division; Irma and Paul Milstein Division of United States History, Local History and Genealogy); and the Office of the Borough President, Manhattan. The main digitized collections we consulted were America's Historical Imprints and America's Historical Newspapers.
} 
found enormous success in introducing the kind of research- and teaching-based, public/private botanical garden that Hosack strove in vain to root in New York soil. Why did one man's efforts lead to the introduction and diffusion of a new organizational form where the other failed?

The origins of botanical gardens lie in the medicinal gardens attached to European monasteries. During the Renaissance, the study of plants and their properties gradually shifted from monasteries to universities, and botanical gardens were established in the 16th and 17th centuries in towns such as Pisa, Padua, Leiden, and Oxford. An early focus of university-affiliated gardens was the training of medical students in plant-based pharmacology as well as the discovery and classification of new plants (Drayton 2000). In the age of European colonial expansion, botanical gardens became increasingly important to national governments interested in the discovery, collection, and diffusion of medically and commercially useful plants, such as Peruvian bark (containing quinine), cacao, coffee, and nutmeg.

Although botanical gardens share certain features with ornamental gardens and public parks, they differ from these cultivated spaces in their central commitment to the scientific use, study, and organization of plants. ${ }^{3}$ The European botanical gardens familiar to Hosack and Britton were first and foremost sites of collection, classification, experimentation, and instruction. Each man incorporated these aspects of specific British botanical gardens as they founded their own gardens in 19th-century New York City. Cognizant, however, of the differences between imperial Britain and the U.S., each carefully fashioned a new organizational form suited to the time and place in which he was working.

\footnotetext{
${ }^{3}$ As an example, consider the case of three Paris institutions: the Jardin des Plantes, the gardens of Versailles, and the Bois de Boulogne. The Jardin des Plantes, originally known as the Jardin du Roi, is a botanical garden that was founded in 1626 by Louis XIII for scientific inquiry into the medicinal uses of plants. The gardens at the Palace of Versailles, constructed for Louis XIV over several decades beginning in the 1660s, were primarily dedicated to the aesthetic display of plants; and the Bois de Boulogne, opened to the public in the 1850s, was primarily intended as an outdoor recreational space. Although the Jardin du Roi contained some "display" gardens and the gardens of Versailles contained some "applied" gardens (such as the jardin potager or kitchen garden), the core functions of these gardens differed from each other as well as from the later Bois de Boulogne. On the complex relations among French botany, horticulture, and political power, see Mukerji (1997).
} 
A meaningful definition of novelty, one that invites scholars to reveal lived human experience, emphasizes the unfamiliarity of a new form to the relevant audiences in the historically specific social context into which it is being introduced. Determining which audiences are relevant and where the boundaries of that social context fall depends on detailed empirical inquiry (Abbott 1995). As we show, these are not cases of mere diffusion. Both Hosack and Britton built organizations unlike any seen in New York City or, for that matter, in the U.S. of their day. Thus although botanical gardens of varying types and missions had long since taken root in Europe, each of our founders sought to introduce what was a new organizational form in his social setting, with widely varying outcomes. These two comparable efforts in the same city at moments marked by different social, economic, and political structures afford an analytic window into the relationship between organizational forms and the social contexts in which they are born.

We begin with a brief discussion of several lines of scholarship that have contributed to explaining the emergence of organizational forms. We cull useful concepts from this work, as well as from our own extensive archival research, to examine our two founders and their efforts to introduce a new organizational form. Attention to the similarities between their projects and biographies throws into relief the differences between their respective historical times. We note that while we find useful analytic purchase in the comparative case method, we diverge from traditional Mill-inspired case comparisons in our central concern to map and take account of the shifting causal relationships between the temporally distant contexts in which our two cases unfold. Instead of comparing the two cases for variables that are absent or present, our examination underscores how, in each case, relations at one level reinforce or hinder relations at another, rendering efforts at agency either viable and widely consequential or local with limited impact. Building on our empirical analysis, we turn to a theoretical elaboration of the concept of poisedness. The conclusion follows with methodological considerations for researchers interested in analyzing the poisedness of other times and places for other kinds of organizational forms. 


\section{THE PROBLEM OF ORGANIZATIONAL EMERGENCE}

Sociology is replete with attempts to theorize relations across levels, from individual interactions to groups, communities, and fields, and on to large political and social structures. Whether the theoretical imagery is Coleman’s (1986) “boat” model, Collins' (1981) interaction ritual chains, Fligstein and McAdam's (2012) nested arguments made via invocation of Russian dolls, or Mahoney and Thelen's (2010) layering, the conceptual language emphasizes aggregation across levels. Such views are a bit too tidy for our purposes. We consider cross-level concatenations in terms of new potentials that did not previously exist but that, once exploited, transform the landscape of what is available. Instead of alignment, in which there is always opportunity for behavior consistent with the past, we show the emergence of the possibility of building something that was not previously in view. To this end, we show that micro-level interactions can generate consequences that are independent of their local origins. Nathaniel Britton labored tirelessly to create the New York Botanical Garden; little did he know how much his efforts would shape other American cities or alter the kinds of roles that successful faculty members could play in public life. These reverberations into urban landscapes and policy circles reflect the amplifying effects of social changes, and reinforce an older point by Stinchcombe (1968) that the forces that create a new entity and those that sustain it are fundamentally different.

In his 1965 work on "Social Structure and Organizations," Stinchcombe reflected on the emergence, persistence, and diffusion of new organizational forms. New forms, he observed, are subject to social liabilities not faced by existing organizations, such as a lack of legitimacy and the unfamiliarity of new organizational roles. Building on Weber's sociology of organizations as well as mid-century interest in political revolutions and the organization of industrial societies, Stinchcombe hypothesized that new forms are most likely to emerge when a prospective founder discovers or invents a new, better way of organizing to accomplish a social or commercial goal. Settings rich in contacts between distinct 
social groups, he argued, are the most hospitable to the emergence of new forms, which persist and diffuse when founders effectively mobilize material and cultural resources and the form is institutionalized.

Stinchcombe's work proved fruitful for the study of organizations. Three strands of inquiry soon emerged to take up his central questions: neoinstitutional theory, social movement theory, and organizational ecology. Initially, neoinstitutional scholars focused on the process by which extant organizational forms are institutionalized and diffused; more recently, a new line of work has sought to explain change in existing organizations as well as the origins of new organizations by focusing on individual efforts to introduce novelty. Social movement theorists, particularly those interested in organizations, have explored how challengers' positions in political structures help them introduce and institutionalize new modes of organizing for collective action. Organizational ecology grew directly out of Stinchcombe's hypotheses regarding how population characteristics affect founding rates and survival chances.

We turn now to a brief review of these literatures, in order to build a toolkit that will aid our overarching effort of explaining how new forms emerge, take root, and propagate. We pay particular attention to how these literatures explain readiness for and the reception of new modes of organizing. In doing so, we take care to situate the concepts we borrow in the theoretical contexts in which they were formulated.

Research on Institutional Entrepreneurship. Neoinstitutional organization scholars seeking to explain how institutional arrangements are altered have turned to the concept of institutional entrepreneurship, highlighted by DiMaggio (1988, p. 14): "New institutions arise when organized actors with sufficient resources (institutional entrepreneurs) see in them an opportunity to realize interests they 
value highly." ${ }^{4}$ Two core concepts, organizational field and institutional logic, have provided the primary building blocks for these studies. In a given field, a dominant logic or competing logics impose material and cognitive-cultural constraints on individual and organizational behavior, as well as providing resources for entrepreneurs seeking to initiate organizational or field-level change (e.g., Beckert 1999, 2010). In this context, institutional entrepreneurs are viewed as creative people whose acumen and social positions—often at the borders between logics—encourage them to recognize problems or opportunities and take advantage of enabling conditions to effect institutional change (e.g., Rao, Monin, and Durand 2003).

Work on institutional entrepreneurship has usefully explored the local processes through which new organizational forms may emerge. As Stinchcombe (1965: 153) observed, those seeking to pursue an identified opportunity have no choice but to work with existing material and cultural resources as they assemble new organizations. Scholars have shown that institutional innovations or inventions often emerge when people transpose or recombine practices and routines taken from outside their primary domain of activity and use them in new ways in different settings (Padgett and McLean 2006; Stark 2009). Recent studies have harnessed these insights to examine how entrepreneurs assemble organizational "templates" that package disparate elements into a new form (e.g., Battilana, Leca, and Boxenbaum 2009).

Templates add shape and strategy to founders' initial ideas. They also provide a common point of reference as founders seek to articulate their vision to others whose support is critical to the successful introduction of a new organization or form (Beckert 2010: 157-9). Success depends, however, not merely on the existence of a clear template, but also on an institutional entrepreneur's ability to communicate the template and its advantages to stakeholders. Such social skill is critical in attempts to

\footnotetext{
${ }^{4}$ Eisenstadt $(1964,1980)$ was the first to coin the term "institutional entrepreneur" in his effort to integrate agency and historical context. Inspired by Weber's work on charisma, he sought to analyze rare but epochal individuals who spark institutional change.
} 
mobilize resources, persuade supporters, and shut down critics (Fligstein 1997, 2001). One concern, however, is that this line of work frequently overstates the power of individuals to orchestrate desired changes. Because the cases studied have almost exclusively involved successful projects, it has been tempting for researchers to seek out confirming signs of entrepreneurs" "heroic" contributions to observed outcomes.

Recently, some scholars have sought to rectify this overemphasis on successful, intentional change efforts by introducing the concept of institutional work (Lawrence, Suddaby, and Leca 2009). This move is meant to encourage a more expansive frame for what kinds of outcomes merit study by covering not only "fresh" action but also efforts to reproduce existing institutions. In particular, scholars working in this vein have called for attention to "institutional biography" via "the exploration of specific individuals in relation to the institutions that structured their lives and that they worked to create, maintain, or disrupt" (Lawrence, Suddaby, and Leca 2011, p. 550). Such arguments encourage organization theorists to ask how biographical trajectories through historically specific institutions shape both the kind of institutional work in which they engage and its chances of success.

Social Movement Theory. A second approach to examining how new forms of collective action emerge has come from social movement theory, which shares conceptual terrain with theories of institutional entrepreneurship. Indeed, many of the major concepts underpinning research on institutional entrepreneurship and work first emerged in research on social movements. Organizationally informed movement research, however, is not directed at individual action in organizational contexts, but instead toward collective action (Fligstein and McAdam 2012, p. 9). McAdam, McCarthy, and Zald (1996, p. 2) identified three factors that were critical to the emergence and development of social movements: political opportunities, mobilizing structures, and framing processes. Political opportunities include the openness or closure of the political arena, the stability or instability of those holding power, the presence or absence of allies for the political elite, and the state's capacity for repression. Mobilizing 
structures include "meso-level groups, organizations, and networks that comprise the building blocks of social movements." Framing processes involve acts of interpretation, attribution, and social construction that mediate between opportunity and action.

This work builds on the insight that new forms may arise when challengers devise novel tools as they seek to change existing arrangements. In her analysis of the women's movement at the dawn of the 20th century, Clemens $(1993,1997)$ shows that as outsiders to the bureaucratic political system, female activists drew on repertoires of organizing from beyond the political sphere as they sought to gain inclusion and influence. Such studies emphasize "the construction of new organizational forms as a political process in which social movements play a double-edged role: They de-institutionalize existing beliefs, norms, and values embodied in extant forms, and establish new forms that instantiate new beliefs, norms, and values" (Rao, Morrill, and Zald 2000, p. 240).

Movements research recognizes that institutional innovation frequently begins with the identification of a problem or of an opportunity to be exploited (e.g., Walker, Martin, and McCarthy 2008). In the hands of an innovator, a problem, once identified, gives rise to an organizational project. Often, of course, the identification of a problem itself represents an opportunity for an innovator to reap material and symbolic rewards through its resolution. There are lively discussions in the literature on social movements regarding why some people are more likely to build new movements or ventures, and others_-equally well, if not better, placed_-miss such opportunities (Sheingate 2003; Clemens 2007). Fligstein and McAdam (2012) note that new forms of action and organization are most likely to emerge in "unsettled" or shifting fields, when people with the skill to mobilize disparate groups recognize and seize opportunities to change the status quo. As but one example, in a compelling analysis of Cesar Chavez and his United Farm Workers' union, Ganz (2000) shows that the AFL-CIO had more money, political clout, and personnel than the group led by Chavez. But Chavez saw the possibility of fashioning a unique winning coalition that forged a new, successful political identity. 
Essential to exploiting new opportunities is the aptitude for doing so. Social movement theorists view successful institutional innovators as people who are able to explain projects in clear but flexible terms that will make sense to multiple, relevant stakeholder groups. At the same time, a frame results in the mobilization of requisite resources only insofar as it is communicated to and accepted by powerful others. Hence the framing of new projects—-that is, the particular arguments, symbols, values, and labels invoked by organizers and supporters - is central to garnering resources and establishing legitimacy (McAdam, McCarthy, and Zald 1996; Benford and Snow 2000). The deft framing of institutional projects helps entrepreneurs overcome such barriers as scarce resources and low legitimacy. Thus social skill encompasses the ability both to develop a meaningful frame and to persuade pivotal individuals to assimilate and publicize it.

In viewing organizational forms as the outcome of political contests, these studies offer insight into political aspects of emergence. Recent work on social movements is also more attentive to larger structural processes affecting the emergence of new forms. As Fligstein and McAdam (2012: 59-64) argue, the embedded and interlocking nature of strategic action fields means that instability or change in a neighboring field may shape opportunities for action in a focal field. The hierarchical nesting of fields may push higher-level changes downward, unsettling relations in a dependent field. Recently, some social movement researchers have begun to express concern about their field's longstanding tendency to focus only on successful mobilization projects. These scholars have called attention to the importance of studying groups that had structural opportunities but failed to mobilize. For example, McAdam and Boudet (2012: 59-60) found that in twenty communities "at risk" for mobilization against proposed energy projects only two showed high levels of mobilization, thus emphasizing that social-structural moments of collective action often go unexploited. This work highlights the historical moments when social structural opportunities for new forms of action and organization present themselves. 
At the same time, social movement research has its own dark spots. In emphasizing that institutional innovation emerges from the actions of under-resourced challengers against well-supported incumbents, this work has been less attentive to an equally important source of institutional change. Incumbents, too, may try to create or support new organizational forms in order to secure or enhance their dominant position (Padgett and Ansell 1993; Powell and Owen-Smith 2012). Conservative elites frequently innovate, sometimes unintentionally, as they try to retain power. In 17 th-century France, for example, Louis XIV facilitated the emergence of a new form — a hybrid of royal academy and public theater-when he offered support to the founder of the first French opera company (Johnson 2007). Organizational Ecology. Working at the most macro-level of the three approaches, organizational ecologists seek to explain the variety of organizational forms - that is, organizational diversity_ - via analysis of population-level dynamics. In the earliest formulations, Hannan and Freeman $(1977,1984)$ identified the concept of organizational form as an analogue to the biological concept of species. Thus "a population of organizations consists of all the organizations within a particular boundary that have a common form" (Hannan and Freeman 1977, p. 935); form is defined as “a blueprint for organizational action, for transforming inputs into outputs” (ibid., p. 934). The central question animating ecological research has been how environmental conditions at the time of a new organization's founding, especially the availability of resources and the array of extant forms, affect its survival chances. Ecologists' early attention to form did not focus on how new forms emerge, but instead on how they are distinguished from one another: "Our goal is not to explain how initial organizational diversity arises, however, but rather to identify the conditions under which discontinuities arise, persist, and disappear" (Hannan and Freeman 1986, p. 51). In most ecological research to date, the determination of forms, and thus the construction of populations, has been grounded in industry codes and classifications, which are typically based on product similarities. 
More recently, however, some ecologists have questioned the appropriateness of such methods. For example, Hsu and Hannan (2005, p. 475) ask, "Do such distinctions based on product correspond to salient identities in the minds of members and external audiences?” Ecologists have drawn on institutional theory and cultural sociology to argue that organizational forms are complex socio-cultural entities arising from the expectations and assumptions of multiple, sometimes conflicting audiences (Pólos, Hannan, and Carroll 2002). This newer work seeks to capture focal populations not on the basis of product similarities codified by analysts but instead on the basis of the experience and perception of a broader range of audiences who interact with the organizations. For example, Carroll and Swaminathan (2000) chart the rise of the microbrewery movement out of some consumers' and producers' discontent with mass-produced beer. They show that competition for customers is shaped not only by product characteristics but also by contestation over what constitutes authenticity—that is, over the "form identity" of breweries. In this recent work, the openness of an ecological niche to a new organizational form is viewed as a cognitive-cultural process (e.g., Smith 2011; Sharkey 2014).

With this approach, the early ecological concept of an organizational blueprint has taken on new life. Ecologists ask how available forms, captured in blueprints for structure and action, are passed down across generations, altered, or otherwise deployed in the creation of new organizations (e.g., Baron, Hannan, and Burton 2001; Hannan 2005). Organizational blueprints have thus come to resemble more closely the templates studied by institutional entrepreneurship and social movement theorists. And as researchers ask how founders poach, recombine, and generate blueprints for new forms, they are similarly investigating the impact of founders' biographies on the choices they make about which blueprints to use or borrow from (e.g., Burton and Beckman 2007).

As ecologists pursue these refinements in the identification of populations and the interpretation of population dynamics, they maintain their commitment to the most significant contribution of an ecological approach: its population-level vantage point. The value of ecology's methodological and 
theoretical concerns has been widely demonstrated. Nonetheless, as literary critic Kenneth Burke (1935, p. 70) famously put it: "Every way of seeing is also a way of not seeing." The priorities of organizational ecology limit our ability to explain the emergence of new forms in two ways. First, working at the population level has deflected attention away from sources of innovation that influence people to found new organizations, such as bricolage, recombination, and transposition (e.g., Vedres and Stark 2010; Powell and Sandholtz 2012). Second, by defining the organizational environment via competition among similar organizations over available resources, ecologists underemphasize a wide range of political and cultural processes relevant to organizational emergence.

Despite these limitations, ecologists provide an important corrective to theoretical approaches that focus on one or just a few organizations at a time and that thereby run the risk of misattributing critical causal processes and outcomes (Carroll and Hannan 2004, p. 4). Recent work also continues to benefit from an expansive temporal scale, which has permitted ecologists to grasp tectonic shifts that go undetected in temporally circumscribed studies: "On a time scale of centuries, the world of organizations changes by selection in the sense of differential replacement” (Hannan 2005, p. 53). By zooming out from a focal organization or organizations to the vantage point of whole populations, ecologists show that the array of available forms shapes both the character of the new forms proposed by innovators and the receptivity of different audience segments to those forms.

The largely independent pursuit of these three lines of inquiry-research on institutional entrepreneurship, social movement scholarship, and organizational ecology—has hindered investigation into the explanation of how new organizational forms emerge. At the same time, these literatures provide indispensable analytical tools, upon which we draw in the next section as we examine our two organizational cases. Our ultimate aim is to explicate when larger structural forces are amenable to, and supportive of, individual-level efforts at innovation. To do so, we need to specify how tools for and models of organizing are made available as a consequence of changes in the material, social, and 
economic environments. Once such scaffolding is available, we will show, it alters the options available to entrepreneurially minded people. We take up this challenge by situating individual efforts at organizational innovation in historically specific configurations of material, social, and economic processes. First, however, we turn to a comparative examination of our founders and their efforts.

\section{“AN ALMOST UNTRODDEN FIELD”: PROJECTS AND ENTREPRENEURS}

In September 1794, David Hosack, a young New Yorker recently returned from medical studies in Great Britain, wrote to his mentor about the urgent need he saw for scientific progress and instruction in botany in the new Republic. In Edinburgh and London, Hosack had found the medical establishment deeply engaged in studying plants to prevent and treat illness. Upon arrival in New York, he wrote to his former professor Benjamin Rush, a signer of the Declaration of Independence and the most famous doctor in the U.S., to describe the access he had been given to British botanical gardens by eminent scientists and doctors. He also exulted in the opportunities for advancing American botany: "I have also, as I may call it, an almost untrodden field in this country for those pursuits."

Hosack recognized and soon seized an opportunity for institutional innovation. As we have seen, organization scholars have developed numerous insightful accounts of how people find traction with novel projects. Although these accounts vary in their particulars, there is some consensus on the elements that are common to successful institutional projects. At the individual level, scholars have emphasized that the opportunity recognition that leads to an innovator's new project is facilitated by her or his biographical trajectory (McAdam 1989; Burton, Sørensen, and Beckman 2002). Biographical trajectories foster the social skill needed to persuade others (Fligstein 2001; Battilana, Leca, and Boxenbaum 2009). They are also important in generating access to sponsors and representatives who connect these people to diverse contacts, resources, and sources of knowledge (Greve and Rao 2012).

\footnotetext{
${ }^{5}$ David Hosack to Benjamin Rush, September 8, 1794, Historical Society of Pennsylvania.
} 
Culturally available organizational templates represent collective resources on which they may draw to articulate a new arrangement and acquire needed legitimacy and resources (Ruef 2000; Haveman and Rao 2006). We synthesize these common elements to offer an initial comparison of the two gardens under investigation here. In what follows, we situate the projects of David Hosack and his Gilded Age counterpart, Nathaniel Britton, with respect to these four elements-project, biography, template, and social skill—critical to organizational foundings.

Hosack's Project. In November 1797, Hosack, by this point a Columbia medical professor, addressed an appeal to the trustees asking for an annual stipend to help establish a botanical garden. Although both European and American doctors believed an understanding of botany to be of critical importance in formulating and prescribing medicines, Hosack found himself teaching New York City's medical students without the aid of a botanical garden. Such a garden would permit Hosack to instruct his students not merely from books but from plant specimens. The primary goal of medical instruction from specimens, both living and dried, was to help students understand how to identify, cultivate, and use known therapeutic plants for the prevention and treatment of illness. Students who developed facility in these areas might also one day identify new plant species and plant-based medicines.

In a young nation whose growing cities were regularly ravaged by yellow fever, scarlatina, and typhus epidemics, the development of new medicines and of doctors knowledgeable about their applications was critical. Indeed, just two months before Hosack applied to the Columbia College trustees for funds, he had used a botanical remedy to save the life of Alexander Hamilton's son Philip, who was deathly ill with typhus (Chernow 2004, pp. 544-5). Columbia agreed, and a committee convened by the trustees recommended that Hosack be allocated 300 pounds annually for the project: "The establishment of a botanical garden appears to be essentially necessary for the purposes of medical instruction" (quoted in Hosack 1811, p. 8). In 1800, Hosack submitted a memo to the state legislature appealing for additional funds; the state's committee was as supportive of the project as Columbia had 
been, reporting that "in their opinion the prayer of the memorialist ought to be granted" (ibid., pp. 910).

Buoyed by this support, Hosack purchased twenty acres of land three and a half miles north of New York City. Surrounded by farms and reached by a country lane, the hilly site afforded a view of both the East and Hudson Rivers. Hosack named his new establishment after his father's birthplace in Scotland, calling it the Elgin Botanic Garden. By 1806, he reported that the botanical garden boasted a conservatory nearly 200 feet long and that the "grounds are also arranged and planted agreeably to the most approved stile [sic] of ornamental gardening" with more than 1500 American and foreign plants (Hosack 1806). He was soon offering regular courses to medical students there in the spring and summer and bringing specimens to his winter classes at Columbia. In addition, Hosack was also growing and collecting native and "exotic" ornamental plants and experimenting with grains, cotton, and other commercial crops.

The Elgin Botanic Garden drew the praise of many prominent contemporaries for its contributions to the scientific life of the city, the state, and the young nation. In 1806, Governor Morgan Lewis opened the legislative term with a speech to the joint session of the New York State Assembly and Senate that singled out Hosack’s establishment (Hosack 1811, p. 12):

I, in the course of last summer, paid it two visits, and am so satisfied with the plan and arrangement, that I cannot but believe, if not permitted to languish, it will be productive of great general utility...."

In the same year, President Thomas Jefferson wrote to Hosack to say that "should he have it in his power to be useful to his institution at any time he shall embrace the occasion with that pleasure which attends every aid given to the promotion of science." "The Elgin Botanic Garden achieved renown in foreign capitals, as well. Eminent botanists in London and Paris_-including Napoleon's own chief botanist—exchanged plant specimens with Hosack throughout the early decades of the 19th century

${ }^{6}$ Thomas Jefferson to David Hosack, September 18, 1806, Thomas Jefferson Papers, Series 1: General Correspondence, Library of Congress. 
(A. Hosack 1861, p. 326). Before Hosack left London in 1794, he had been elected a fellow of the Linnean Society, repository of the most famous botanical collection in the world; after the founding of Elgin, he was also elected to the American Philosophical Society and the Royal Society of London.

Britton's Project. Ninety years later, in 1891, Professor Nathaniel Britton founded a 250-acre botanical garden in New York City that was second in size and organizational complexity only to the Royal Botanic Gardens at Kew, England. Two years earlier, in 1889, Britton and his wife had visited Kew on their honeymoon; when they returned, they spoke to their fellow members at the Torrey Botanical Club, a Columbia-based association, about the possibility of founding such an ambitious garden in New York. That year, under Britton's leadership, the club published a statement arguing that "a botanic garden of the highest class, established in New York City or its immediate neighborhood, would be placed at the best imaginable point to win a lasting reputation for itself and its founder, both in this country and abroad" (Torrey Botanical Club 1889, p. 4).

Armed with this proposal, Britton set about enlisting the support of New York's political and social elites. In 1891, he saw his efforts come to fruition. That April, Governor Roswell Flower signed an "Act... to Incorporate the New York Botanical Garden" that set aside a large parcel of city-owned land to be given to the garden if, by 1898 , its founder had raised $\$ 250,000$ in private funds. Britton did so by 1895, with the help of Columbia University and individual donors including Carnegie and Rockefeller. With these considerable resources secured, Britton oversaw the construction of the facilities needed to establish a botanical garden on a grand scale. In 1901, work was completed on a massive Italianate building that housed the herbarium, the library, laboratories, classrooms, and exhibits on systematic and economic botany. In 1902, Britton announced the opening of the biggest conservatory in the U.S., enclosing 45,000 square feet under glass. Over the next decades of Britton's tenure as Directorin-Chief, he supervised the cultivation of the grounds and expansion of the living and preserved specimen collections. When he retired in 1929, the NYBG held more than 1.5 million specimens. 
From their respective vantage points at either end of the 19th century, Hosack and Britton each recognized an opportunity and worked doggedly to realize their visions. Clearly, opportunity recognition is a necessary, if not sufficient, element in such innovation. Why, then, were these men poised to recognize these particular opportunities? The course of personal lives is bound to historical times, as differences in birth year expose people to quite distinct social worlds.

Hosack's Biography. Hosack was born in 1769 in Manhattan. After a childhood spent largely under the British occupation (1776-1783), he enrolled in 1786 at Columbia, then located at Park Place in lower Manhattan. There Hosack began a lifelong friendship with DeWitt Clinton, who would become a US Senator, New York City mayor, and governor of New York. In 1788, Hosack transferred to the College of New Jersey at Princeton, graduating in 1789 (Robbins 1964, p. 20). His growing interest in medicine took him next to the University of Pennsylvania, where he enrolled in autumn 1790.

On completion of his medical studies in Philadelphia, Hosack moved with his new wife to Alexandria, Virginia, to begin practicing medicine near the future US capital. Within a year, however, he decided to further his studies in Edinburgh and London, where he learned firsthand of the importance of botany and botanical gardens to European medical education and practice. He resolved "whenever an opportunity might offer, to acquire a knowledge of that department of science” (A. Hosack 1861, p. 297). In late 18th-century London, a hotbed of botanical research, he found his opportunity. There, in the summer of 1793, Hosack studied daily at the Brompton Botanic Garden, and in 1794 he attended lectures given by the most eminent English botanist of the era, James Edward Smith, who invited him to study in the collections of the renowned Linnaean Herbarium.

On his return to New York, Hosack joined the medical practice of Samuel Bard, whose patients included Washington, Hamilton, and Burr. In 1795, Hosack was appointed Professor of Botany at Columbia, and in 1796 he became Professor of Materia Medica. Over the next decades, he became a pillar of the city's scientific and cultural life, helping to found the New-York Historical Society, the 
New-York Horticultural Society, the Academy of Fine Arts, and the Literary and Philosophical Society. He counted some of the most famous New Yorkers, and indeed Americans, among his patients and friends. Burr and Hamilton were both longstanding clients of his medical practice, but it was his close friend Hamilton whom Hosack attended at the fatal 1804 duel (Chernow 2004, p. 706). Among his many correspondents on scientific, cultural, and political matters were Sir Joseph Banks (president of the Royal Society), James Madison, and Thomas Jefferson. Hosack became the leading doctor in New York City, known for his innovative treatments of a wide range of medical conditions, from scarlet fever to infertility. He ministered to the most prominent New York citizens and was the medical expert chosen to testify at the most famous murder trial of the era.

Hosack's trajectory thus took him from the top medical school in the young Republic to immersion in Britain's much older medical establishment, with its reverential attitudes to botanical study and application. Returning to his native terrain, he turned fresh eyes on American medical training and practices and immediately saw opportunities that others had not. Nathaniel Britton, born in New York ninety years after Hosack, began his trajectory at a very different moment in the history of his country and his city, but just as for Hosack, it was a trip through the world of British botany that helped him see an opportunity for institutional innovation in the United States.

Britton's Biography. Britton was born in 1859 on Staten Island. After demonstrating a strong interest in botany as a child, he studied botany and geology at Columbia, located since 1857 at $49^{\text {th }}$ Street and Madison Avenue. In 1879, Britton received an Engineer of Mines degree from Columbia's School of Mines and joined the New Jersey Geological Survey as its botany specialist (Howe 1934, p. 171). Two years later, he earned his $\mathrm{PhD}$ with a dissertation entitled "A Preliminary Catalogue of the Flora of New Jersey" (Mickulas 2007, pp. 54-5). Over the next five decades, he published hundreds of articles and many books on botany (Howe 1934, p. 172). Britton's accomplishments as a student and with the New 
Jersey Geological Survey led to his appointment in 1890 as an adjunct assistant professor of botany at Columbia. In 1891, he was promoted to professor of botany (Sloan 1980, p. 57).

Britton was an active member of New York's intellectual life and an instrumental figure in local scientific societies. As an undergraduate, he joined the Torrey Botanical Club, New York's main organization for professional and amateur botanists. Named for John Torrey, a Columbia chemistry professor who first convened the gatherings in the 1860s, the club offered its members a forum for the discussion of plant specimens and the presentation of scientific papers (Mickulas 2007, p. 37). Under Britton's editorship (1889-1897), the monthly Bulletin of the Torrey Botanical Club became a significant outlet for advances in botany (Merrill 1938, p. 149). In 1880, before Britton had even completed his PhD, he was elected a member of the New York Academy of Sciences; he rose to its presidency in 1906. He was instrumental in proposing and founding the Scientific Alliance of New York, created in 1890 to gather together the many scientific societies in the city (NYAS 1935, p. 88). As his prominence in New York scientific circles rose, Britton began to gain national recognition. He had attended the annual meetings of the American Association for the Advancement of Science (AAAS) since 1884 (Gleason 1960, p. 208). By 1892, the botanists of the AAAS formalized their section into an independent organization, which was constituted in 1893 as the Botanical Society of America. Britton was elected one of ten charter members; he was elected vice president in 1894 and president in 1898.

When Britton returned from his honeymoon visit to the Royal Botanic Gardens at Kew in 1888, he was poised as both a scientist and a citizen to mount a campaign for a similar establishment in New York City. His reputation as a leading American botanist was complemented by his institutional ties to Columbia. When Britton was a Columbia student, his mentor had been John Strong Newberry, a professor of geology and paleontology who galvanized New York's scientific life as president of the New York Academy of Sciences and who was a charter member of the National Academy of Sciences (Sloan 1980, p. 39). As a Columbia professor, Britton enjoyed unusually close ties to Seth Low, the 
college's well-connected president (and a future mayor), who had already begun to figure in the city-wide movement to harness New York's financial and social resources in the service of cultural and educational institution-building. Like Hosack, Britton enjoyed a personal and professional trajectory that allowed him to recognize the possibilities for institutional innovation in American botany.

Personal experiences predispose certain people to observe opportunities more readily than others. Such recognition is not, however, sufficient; otherwise the world would have many more successful new ventures. The challenge also lies in creating a model and fashioning an accompanying narrative that enrolls others. The ability to "connect the dots" between one's knowledge of a market or field and the recognition of an opportunity depends, in part, on constructing a template that enables one to perceive connections between seemingly unrelated changes or events. A template provides narrative materials that help innovators convey their vision to others who can help them realize it. Whether in the form of a prototype that signals an emergent pattern or an exemplar that builds on past experiences, the people who attempt to build new organizations need to construct a suitable and persuasive template for their projects. Precisely which practices and forms appear appropriate or desirable to these innovators depends in large part on their biographical trajectories through specific social and professional milieux.

Hosack's Template. When Hosack proposed the founding of a botanical garden in the late 18th century, the U.S. offered no organization that conformed to his vision. There was, simply put, no US model available to him. The handful of gardens in operation in the late 18th century were run by private citizens, not institutions, and none were used for formal medical training. The most famous of these was the nursery established outside Philadelphia in the 1720s by John Bartram and carried on by his son William. The Bartrams collected plants and seeds from around the world and also sent thousands of specimens from the American colonies to European correspondents, who used them both for scientific research and to adorn private gardens (Wulf 2008). Neither this garden nor the few others 
dotted along the Eastern seaboard was anything like the scientific and educational enterprise Hosack envisioned.

For his template, Hosack turned primarily to the British garden tradition, which he had imbibed through scientific excursions in London's Brompton Botanic Garden and study in the Linnean Society collections. Thanks in no small measure to the participation of the botanist Joseph Banks in the South Sea voyages of Captain Cook, England in the late 18th century was filled with botanists. The Brompton Botanic Garden was a private enterprise established soon before Hosack's arrival in London by a botanist named William Curtis, who supported his garden via subscriptions to his wildly popular botanical magazine. At the Linnean Society, a private organization comprising a museum, herbarium, and library, Hosack studied the plant classification system of the eminent Swedish botanist Carl Linnaeus (1707-1778). While in London, he also learned about a rival classification system established by the French botanist Antoine Laurent de Jussieu (1748-1836), which was espoused at the (formerly royal and then republican) Jardin des Plantes in Paris. Hosack also learned about the Royal Botanical Gardens at Kew, outside London and not yet open to the public, where Sir Joseph Banks was chief botanist to George III and the Linnaean system prevailed.

As he worked to found the Elgin Botanic Garden, Hosack strategically recombined central elements of these gardens to fashion a new kind of garden suited to the context of the early Republic. He had brought a number of dried specimens back from London, including some from Linnaeus' own collection, and to these he added indigenous and non-native plants cultivated from seeds sent to him by friends and correspondents. Inspired by Kew, Brompton, and the Jardin des Plantes, he drew on the systems of both Linnaeus and Jussieu to organize his garden in a manner calculated to best teach medical students about the science of botany and its pharmacological applications.

At the same time, Hosack jettisoned many elements of the European models that would not be useful in America. Although botany was of interest to many gentlemen in Hosack's social milieu, the 
broader public was not sufficiently engaged to permit him to raise funds via a magazine subscription, as had been done at Brompton. In the absence of a monarchy, Hosack could not appeal for royal patronage to bankroll scientists, donate land, and buy specimens, as had been done at Kew and Paris. Instead, in addition to putting his own money into the enterprise, Hosack sought funding from Columbia College and the state legislature. He knew that Columbia's efforts to establish itself as a college rivaling the University of Pennsylvania and Harvard would be boosted by its affiliation with the first botanical garden in the new Republic. The state legislature, for its part, was deeply interested in the medical, agricultural, and commercial progress of New York, and Hosack tailored his garden to meet these needs.

Britton's Template. Late in the century, Nathaniel Britton also turned to London, and Kew in particular, for his template, but he too recombined elements from the British tradition with newly fashioned elements suitable to his time and place. Kew, founded in 1759 as a private royal garden and made public in the 1840s, had become increasingly important to the British colonial economy in the second half of the 19th century. When Britton first visited in 1888, the garden already boasted nearly seventy acres of display gardens, but its primary activities were research and publication. Its first appointed director, William Jackson Hooker, who took up his post in 1841, was a Scottish professor of botany who was instrumental in building the garden's collections of living and dried specimens and developing its research activities (Brockway [1979] 2002, p. 80). Hooker also set up a Museum of Economic Botany at Kew, which displayed — and made available for medical and industrial researchspecimens collected from around the world on British colonial expeditions (Drayton 2000, p. 194). Botanical training and research on the specimens were conducted in laboratories built for that purpose.

As Britton began to organize his new garden, he turned to Kew for ideas:

To serve adequately the various uses here indicated a botanic garden requires a somewhat spacious site. The Royal Botanic Gardens at Kew comprises sixty-seven acres, an area ample for its purposes. Fifty acres might be considered a reasonable amount of land for a New York botanic garden; half as much 
could be made to answer a good purpose; seventy-five acres would be none too much for its ultimate highest development...” (Torrey Botanical Club 1889, p. 4).

In December 1890, Britton wrote to the director of Kew requesting information about its annual budget. He received a reply the following month: "Kew costs the Government in round figures $£^{20,000}$ a year. I enclose herewith a printed list of our staff which will give you an idea of our organization.”’7

Britton's plan for an "American Kew," as the newspapers called it, represented a major innovation for botany in the U.S. Although several small botanical gardens had emerged in the U.S. between the founding of Elgin and Britton's return from England, none approached Kew's organizational and scientific scale. If New York's new botanical garden were to attain the stature of Kew, Britton would need to establish laboratories, libraries, an herbarium, and a museum, in addition to laying out extensive grounds and building a collection of living specimens. Britton's correspondence from the 1890s shows this is what he set about doing. In October 1896, he wrote to an associate, "I have been occupied continuously for the past three months in endeavoring to get the Garden plans completed in every detail that seems desirable to incorporate in them...I am receiving a flood of material from all kinds of sources, living plants, museum and herbarium material, books and pamphlets and have a really enormous lot of stuff promised as soon as the buildings are ready for it."»

With neither land nor financial support, however, Britton would not be able to house his growing collections. Just as Hosack had before him, Britton reworked the British model to suit an American context in which no royal funds were available to donate land, purchase specimens, and support a scientific staff. In order to mobilize these crucial resources, Britton had to frame his project in a way that would appeal to the most powerful New Yorkers. As we show next, both David Hosack and Nathaniel Britton were highly capable in their articulation of frames that resonated with the most powerful members of their respective scientific, cultural, and political communities. They accomplished

\footnotetext{
7 William Thiselton-Dyer to Nathaniel Britton, January 4, 1891, Britton Papers, Mertz Library, NYBG.
}

${ }^{8}$ Nathaniel Britton to W. A. Stiles, October 29, 1896, Britton Papers, Mertz Library, NYBG. 
this in three ways: lecturing and writing about their projects; enrolling the press; and harnessing their visions to extant organizations, especially Columbia.

Hosack's Social Skill. In the first decade of the 19th century, David Hosack produced a series of pamphlets, letters, and speeches as he sought legitimacy and finances for his new enterprise. His central argument concerned the importance of a botanical garden to improving medical education in the U.S.; American doctors, he asserted, should have the level of training and expertise long since standard in Europe. In the preface to his 1806 Elgin catalogue, he sounded this theme forcefully:

Hitherto the botanical gardens of Edinburgh, Oxford, Cambridge, London, Paris, Copenhagen, Leyden, Upsal, Goettingen, \& $\%$. have instructed the American youth in this department of medical education; and it is in some degree owing to those establishments that the universities and colleges of those places have become so celebrated, and have been resorted to by students of medicine from all parts of the world (Hosack 1806, p. vii).

This framing was meant to appeal to Hosack's medical colleagues and other men of scientific learning in the young Republic (not least President Jefferson) who were familiar with those eminent institutions.

To his medical arguments Hosack frequently added references to Elgin's potential contributions to the progress of American agriculture. In an 1803 lecture at Columbia, he noted:

The student of agriculture will also here have an opportunity of observing, at a single view, the various grasses which compose our pastures and those which are injurious as weeds, or poisonous to cattle. For this purpose, a quarter will be applied to cultivation of this description of plants: in which not only the native grasses of this country will be exhibited, but those likewise which are esteemed most useful in different parts of the world (Hosack 1803, p. 2).

The progress of agricultural production was a concern that cut across social classes. In 1792, a group of prominent New Yorkers—-many of whom were to become friends and associates of Hosack—had founded the New-York State Society for the Promotion of Agriculture, Arts, and Manufactures (NYSSPAAM). Hosack himself joined in 1794. The Society's members sought to collect and disseminate knowledge about "the different modes of agriculture that are in practice; to suggest such improvements as may be found to be beneficial; [and] to excite among their fellow citizens, a spirit of making 
experiments for the amelioration of lands which have been exhausted, or in their natural state are unproductive or unfit for cultivation" (NYSSPAAM 1801, p. vi).

Even though elite New Yorkers generally prized scientific learning as well as the increasing selfsufficiency and prosperity of the United States, the Society reached further to recognize the critical contributions made to these goals by farmers themselves. They took "into fellowship a number of respectable characters throughout the state, from whose talents and diligence they have much to expect," circulating to these farmers a questionnaire that included queries such as "What kinds of grains or grass are found by experience to thrive best in any particular soil?” (NYSSPAAM 1801, pp. x-xi). Thus when David Hosack described the agricultural benefits to be had from the Elgin Botanic Garden, he sought to appeal to the largest possible group of supporters, especially among the state's legislators, whose backing he needed for long-term funding.

Hosack's efforts to publicize the medical and agricultural benefits of his botanical garden bore fruit in newspapers and magazines from one end of the country to the other. Numerous periodicals published lengthy paeans that drew almost verbatim on Hosack's language. In 1810, for example, shortly after he distributed a pamphlet entitled "Description of the Elgin Garden” (Hosack 1810), the Georgia Journal published an equally enthusiastic account that closely echoed Hosack's own turns of phrase: "The interior is divided into various compartments well calculated to instruct the student in the science of Botany by exhibiting to his view not only the plants which are used in medicine, but those that are cultivated by the agriculturalist, and which are employed in the arts and in manufactures" (Georgia Journal, May 1, 1810, p. 4).

Hosack also linked his nascent enterprise to the agendas of other organizations including NYSSPAAM, the Medical Society of the City and County of New-York, the New-York Hospital, and Columbia College. His proposed garden was greeted with marked enthusiasm by fellow New York physicians, medical professors, and students, who delivered a series of written statements in Hosack's 
support to the New York State Legislature. ${ }^{9}$ For Hosack, as later for Britton, Columbia's enrollment in his project was critical. As he worked to build Elgin's greenhouses and collections, Hosack was also integrating his new organization into the routines of Columbia's medical school by offering botany courses at the garden in the summer and in the cooler months using garden specimens in the classroom.

Britton's Social Skill. The close of the 19th century saw Nathaniel Britton building alliances equal to Hosack's at the century's opening. Like Hosack, Britton emphasized both the scientific and practical contributions of his new enterprise and its potential elevation of the American profile in these areas vis-à-vis Europe. Also like Hosack, he tailored his accounts to the concerns of various contemporary constituencies. Describing the purposes of botanical gardens, he and his fellow Torrey Botanical Club members noted that "first and foremost is the purely scientific and educational use. Subsidiary to this, but still of a marked degree of importance, are the pharmaceutical and horticultural uses, and lastly, the general use as a place of agreeable resort for the public at large" (Torrey Botanical Club 1889, p. 2). Britton was also adept at communicating his organizational template via the press. In March 1891, the New York Times published an editorial entitled, "An American Kew Proposed," that drew nearly verbatim on language supplied by Britton himself:

It is desired to give this city not merely a beautiful pleasure garden for popular recreation and instruction, but a great scientific institution of high permanent value... Every city of any importance in Europe has a botanic garden. There are more than three hundred of them. The most important are the Kew Gardens, six miles from London, the Jardin des Plantes at Paris, the Royal Botanic Gardens and Museum at Berlin, and important gardens at Geneva, Rome, Florence, Padua, Vienna, and St. Petersburg (New York Times, March 8, 1891, p. 13).

As fundraising and planning for the garden went into high gear, Britton reminded the press of the importance of rivaling Kew's scientific and practical contributions. In a circular letter he sent to many newspapers and magazines in the summer of 1895, he called upon the public to be mindful of the great

\footnotetext{
${ }^{9}$ For example, an 1810 statement from the Medical Society of the City and County of New-York reads, in part, "a botanic garden is absolutely necessary to complete the means required, for attaining a finished medical education.... On this subject there is no difference of opinion among your medical brethren in New-York" (Hosack 1811, p. 24).
} 
sums needed if this goal was to be accomplished. Just a few weeks later, an editorial in Harper's Weekly (1895, p. 718) adopted his framing:

A botanical garden, it must be remembered, is not a mere pleasure-ground. It ought to be a centre of scientific research, and a fountain-head of that knowledge of plant life which is so essential to the development, protection, and preservation of animal life....Why should not New York's Botanical Garden aim to be in time to North America what Kew is to Europe?

Britton also made sure that his lectures in support of the garden reached a broader audience. An August 1896 address to the botanical section of the American Association for the Advancement of Science at the annual meeting in Buffalo was reprinted in Science magazine just ten days later (Britton 1896), and Britton also sent copies of the text to popular periodicals, explaining to an associate:

I thought when I wrote the document that this might be a good thing to do with it, and worded it somewhat for the purpose. The only thing that I hesitate about is that it may be too much published. It is in Science, in Garden \& Forest, and in Bulletin Torrey Club [sic], and abstracts of it in the Newspapers... ${ }^{10}$

Like Hosack, Britton recognized the importance of anchoring his new project to Columbia College at both the administrative and the instructional levels. Here again Britton introduced a variation on the Royal Botanic Gardens, which were not attached to a university. As early as 1891, Britton engaged President Seth Low in conversations about the possible relationship between the college and the planned garden. Working with Low, Britton secured the transfer of Columbia's herbarium and botanical library to the new garden. The two drew up a legal agreement that institutionalized the interorganizational ties by stipulating that Columbia faculty and students would be allowed unfettered access to the herbarium and library, and that the college would be permitted to offer free classes at the garden to its students in botany, pharmacology, and any other "kindred subjects" (New York Botanical Garden 1896, pp. 19-20). Britton, like Hosack before him, displayed great savviness as he articulated his institutional project and bound it to the routines of Columbia College.

${ }^{10}$ Nathaniel Britton to Charles F. Cox, September 21, 1896, Britton Papers, Mertz Library, NYBG. 


\section{Common Elements, Divergent Outcomes}

Both Hosack and Britton were talented men who innovated in the context of their time. Yet despite the striking parallels between these men and their visions, the outcomes of their efforts differed dramatically. The Elgin Botanic Garden collapsed, physically and organizationally, within fifteen years of its founding. Hosack's organizational innovation flourished briefly, but failed to take root, nor did it inspire the founding of other similar organizations. Hosack had argued passionately that such an important and ambitious scientific undertaking was worthy of, and indeed required, government support. Yet despite the vocal support of his fellow physicians and many politicians in the state legislature, bills introduced in support of Elgin repeatedly failed to win full legislative backing.

In February 1800, a state legislative committee recommended that Hosack be paid 300 pounds, but no actual bill was introduced (Hosack 1811, pp. 9-10). In March 1805, Hosack submitted another petition to the legislature and a second committee recommended support, but again no bill was taken up in the larger body (ibid., p. 11). In January 1806, Governor Lewis recommended in his opening address to the legislative session that the legislators offer ongoing support to Elgin (ibid., p. 14). This time a bill was introduced, receiving a "yes" vote in the state senate and a referral to the state assembly, only to be subsequently dropped from consideration by the lower house (ibid., pp. 12-14). In 1808, Hosack submitted another appeal to the legislature; he was given strong written encouragement but was simultaneously informed that the session was too far advanced to introduce a new bill.

He renewed his efforts at the beginning of the 1809 session, with support from many New York doctors and medical students (ibid., pp. 15-17). These supporting statements bolstered his case, and after protracted deliberations, the state of New York passed an "act for promoting medical science in the state of New-York" that pledged to purchase the Elgin Botanic Garden. The state's patronage fell short, however, of allocating funds for the garden's maintenance, and it soon fell into disrepair. ${ }^{11}$ In

${ }^{11}$ A proposed botanical garden at the University of Pennsylvania ran into similar difficulties. On March 19, 1807, 
1814, the state donated the garden to Columbia College, which had been appealing to Albany for financial help. Instead of funds, the college found itself saddled with a plot of land that successive administrations considered a poor substitute for liquid assets. The garden thus continued to decline under Columbia's ownership, triggering frantic and frequent letters from Hosack to the administration about the death and theft of plant specimens.

Hosack had hoped that Elgin would eventually rank alongside the great botanical gardens of Europe. He had also envisioned that it would train many generations of American doctors and botanists and lead to the creation of a network of botanical gardens in the U.S. It fell prey, instead, to the pressures and opportunities of expanding urbanization. At the time of Hosack's death in 1835, streets were being opened through the old garden land, and by the 1860s, Columbia had begun to sell off small parcels. In 1928, Columbia leased the remaining land to John D. Rockefeller, Jr., for his new Rockefeller Center project; in 1985, Columbia sold the land to the Rockefeller Group for $\$ 400$ million (New York Times, June 3, 1993, p. B3). Today, visitors to the site of David Hosack's Elgin Botanic Garden will find themselves walking through Rockefeller Center. At the corner of Hosack's land, on the spot where his conservatory once stood, is Radio City Music Hall.

Visitors to the NYBG, by contrast, can still tour Britton's original museum building and conservatory and stroll through nearly 250 acres of forested and cultivated grounds. Generations of the Pennsylvania State Assembly passed an act granting “to the University of Pennsylvania the sum of $\$ 3000$ out of the monies they owe the State-for the purpose of enabling them to establish a Garden for the improvement of the Science of Botany, and for instituting a series of experiments to ascertain the cheapest and best food for Plants, and their medical Properties \& Virtues" (Ewan and Ewan 2007, p. 553). Because the funds thus "allotted" were not actually in the possession of the university, the garden was never established (ibid., p. 554). A garden established in Cambridge, Massachusetts, in 1807 had better luck initially thanks to its early funding by a group of private subscribers, although it was outfitted with neither an herbarium nor a botanical library (Harvard 1846). This garden soon began to languish from lack of funds, barely surviving until the galvanizing appointment in 1842 of Professor Asa Gray, a rising botanical star then teaching at the University of Michigan. In the early 1870s, Gray lobbied unsuccessfully to acquire for the botanical garden the bequest of merchant James Arnold, whose money went instead to the creation of an arboretum in Jamaica Plain. The most successful American botanical garden before the founding of the NYBG was Shaw's Garden in St. Louis. Founded as a private garden by the philanthropist Henry Shaw in the 1850s, it was opened to the public in 1859 and renamed the Missouri Botanical Garden. This garden, however, had very limited research and teaching components until after the founding of the NYBG (Grove 2005, p. xv). 
botanists and biologists have trained at the organization Britton founded in the 1890s, and as we discuss below, soon after the garden's successful creation, civic leaders across the U.S. were inspired to launch similar campaigns to establish botanical gardens in their own cities. Within one generation, botanists trained at the NYBG began to advance the discipline in gardens, universities, and associations across the country. Britton also helped usher in a new era in American philanthropy by successfully mobilizing private fortunes and state funding in support of a public-serving organization managed by academic experts. In short, where Hosack failed to gain longstanding traction for his novel organizational form, Britton's innovative effort took root and spread, transforming American cities, science, and philanthropy in the process. (Table 1 provides a summary of the two empirical cases. For portraits of Hosack and Britton, see Figures 1 and 2.)

-Table 1 here-

-Figures $1 \& 2$ here-

In the foregoing analysis, we have made use of a cluster of concepts-projects, biographies, templates, and social skill— that organization scholars have identified as instrumental in explaining the successful creation of a new organizational form. With the aid of this conceptual toolkit, we have seen that both Hosack and Britton were gifted, well-connected men who articulated innovative projects that powerful contemporaries praised for their great scientific and cultural significance. These concepts have been indispensable in helping explain these two innovators' ability to garner support from the most influential people of their era. Nonetheless, the toolkit does not account for why only one of the projects led to the emergence and spread of an American model for botanical gardens. The three approaches from which we have built this toolkit—institutional research, social movement theory, and organizational ecology_ offer only modest help in explaining the divergent outcomes.

First, research on institutional entrepreneurship squarely locates the sources of success in the aptitude and resources of the innovator. From this perspective, Britton's success can be traced to his social position and high degree of social skill in articulating the appropriateness and importance of his 
organizational template. Yet, as we have seen, Hosack—whose organization did not take root—was equally, if not better, positioned and gifted. Additionally, although research on institutional entrepreneurship has produced tools for explaining how entrepreneurial individuals find success in fashioning new organizational forms, such research does not ask why and how some social settings produce such people in the first place. We show below that the decisive differences between Hosack and Britton lie not in the individual men, nor even solely in the field of botany, but in pronounced changes in American material, organizational, and professional life, as well as in the reverberations of those transformations for university careers and individual opportunities.

Second, the emphasis by social movement theorists on "challengers" working against “incumbents” belies Britton's experience. He was indubitably an incumbent in his social world, yet he enjoyed tremendous success in his organizational project. Furthermore, it was Hosack-not Brittonwho was working in a new and highly fluid field where critical resources had not yet become concentrated; therefore Hosack should have had the advantage over Britton with regard to the assembly of resources, and hence more room to maneuver.

Third, ecologists have argued that new organizational projects are likely to be more successful in niches that are experiencing many foundings but that are still rich in unclaimed resources. Both the early Republic and the Gilded Age were extremely active periods of organizational foundings, and Hosack and Britton were both adept at pursuing material and cultural resources. From an ecological perspective, the two projects had comparable chances of success, yet only Britton prevailed. In the analysis that follows, we retain ecologists' powerful macro-level vision but expand it to encompass other critical factors that have previously escaped notice, such as changes in the organization of science and in the built and natural environments. In addition, we diverge from ecologists' conception of entrepreneurs' biographical trajectories primarily as providing organizational resources such as blueprints for 
employment relations in a new venture. Instead, we seek to show how larger structural shifts, in turn, generate entirely new biographical trajectories and thus new kinds of actors.

In the next section, we take up the question of why these strikingly similar organizational projects met with such divergent fates, showing that the answer lies in the dramatic differences between the worlds into which Hosack and Britton were born and between the kinds of individuals those worlds produced. We do so with three goals in mind: first, to make clear how material and cultural factors allow particular models to be viewed as either appropriate or welcome; second, to illustrate how the organizational character of the wider era, viewed here as models of both how tasks should be organized and how expertise is distributed, shaped the topology of the possible (Fontana 2006; Padgett and Powell 2012, Ch. 1); and third, to demonstrate how social structures produce actors poised to recognize and act on possible opportunities. Examining poisedness - matching the character of innovative models with the structural features of the society into which they are introduced-is essential to explaining why new forms persist and propagate, as in Britton's case, or fall by the wayside, as in Hosack's.

\section{“CHIEF CITY OF THE NEW WORLD": MACRO-HISTORICAL CHANGE AND NEW YORK CITY IN THE 19TH CENTURY}

In the first decade of the 19th century, David Hosack was unable to persuade his fellow citizens that a botanical garden was central to the scientific and cultural stature of New York City. In the last decade of the century, Garden and Forest magazine (1895, p. 261) published an article in support of Nathaniel Britton's campaign for a botanical garden celebrating the fact that "New York is to have a garden worthy of its rank as chief city of the New World." The historical shifts that had unfolded over the course of the century rendered the organizational form of a botanical garden not only reasonable to New Yorkers but in fact deeply desired.

First, the urbanization of Manhattan triggered dramatic changes in the way New Yorkers viewed the natural world. Second, the accumulation of industrial fortunes during the 19th century gave rise to a 
new class of moneyed New Yorkers whose travels on the "Grand Tour" exposed them to the cultural and scientific institutions that were the pride of European cities - museums, libraries, opera houses, orchestras, and botanical gardens_ — and also made them aware of the scale of private patronage that would be needed to maintain such institutions in the absence of a monarchy. Third, transformations in the organization of expert knowledge replaced the polymaths of the early Republic-men who were at one and the same time politicians, doctors, and writers, or lawyers, painters, and philanthropists—with disciplinary specialists and professional managers, to whose expertise Gilded Age industrialistphilanthropists deferred.

The changes in Manhattan Island over the course of the century, the new organizational landscape, and the professionalization of science made the prospect of a public-private partnership for a research garden considerably more plausible and fundable. These processes not only reinforced and amplified one other but also contributed to the production of Nathaniel Britton as the very type of person—an academic expert in a organizational world that rewarded professional expertise—who was poised to capitalize on and expand these processes as he introduced his new form. In this section, we discuss central elements of these three processes in order to show how Britton, but not Hosack, operated in a historical context that was poised for the introduction of a world-class botanical garden.

\section{The Material Environment of 19th-Century New York City}

Human interactions with the material world profoundly condition both the ends to which organizations are put and the technologies designed to accomplish them, a point that organizational sociologists beginning with Weber have acknowledged. "Social life," as Mukerji (2009, p. 13) has argued, "is always dependent on the material possibilities of places and gives rise to forms of intellect that make sense there." We suggest that organizational forms should be counted among the "forms of intellect" made possible by historically and geographically specific dispositions of the material world. As we show, 
the organizational form of a botanical garden could not be rendered meaningful to the required constituents of Hosack's New York. The material disposition of Manhattan Island and the ways of thinking about the built and natural environments embodied in that disposition precluded full acceptance, and thus full support, of a botanical garden. By the end of the century, however, the transformation of Manhattan Island and its environs would render the organizational form of a botanical garden not only sensible but desirable.

In 1800, New York City occupied only the southern tip of Manhattan Island and had a population of about 60,000 . Although the city itself was densely built, with busy shipping, commercial, and residential districts, most of the island remained bucolic. North of Bleecker Street (today's Greenwich Village) lay a sparsely populated landscape dotted by woods, streams, country estates, and farms. The famous New York City grid, which would give structure to the spread of buildings and streets on Manhattan, would not be mapped on paper for another decade, and it would take many more decades to unfold up and across the island. Concerns about the loss of green space that would lead to the creation of Central Park in the 1850s had not yet been voiced.

In this specific natural-environmental context, Hosack-unlike Britton nearly a century latercould hardly appeal to the importance of protecting Manhattan farmland from development by enclosing it behind the walls of a botanical garden. The difficulties Hosack faced in making his case are evident in an 1811 speech by a prominent professor of medicine in the city, Dr. Nicholas Romayne, who argued that it would be foolish for the state to purchase Elgin, for "in a country where every farm and forest affords a variety of plants sufficient to illustrate the principles of Botany, public animosity may be aroused" (Romayne 1811, p. 123). Unlike the urban botanical gardens of London and Edinburgh, a botanical garden on Manhattan Island in the first decade of the 19th century was too easily camouflaged by its rural surroundings. For the uninitiated, its institutional significance as a site for the production of locally and nationally valuable medical and agricultural knowledge was not evident from 
its physical appearance. Furthermore, by pasturing cows on part of the land, Hosack generated earned income for his organization, but inadvertently contributed to misunderstandings about its nature. "These animals, to the number of 20 or 30, attend the Botanical Garden and excite the ridicule of travellers passing there" (College of Physicians and Surgeons 1812, p. 18). Thus opponents who recognized the organizational form Hosack was attempting to establish but wished to thwart him for academic and social reasons found this identity problem could be handily deployed as a weapon in the struggle over the allocation of prestige and funds.

On the national scale, as in New York City, the early Republic was characterized by a sense of natural abundance. At the outset of the 19th century, President Thomas Jefferson had doubled the size of the United States with the Louisiana Purchase and sent Lewis and Clark on an expedition to map the geography, flora, and fauna of the unknown continent. In 1825, the inventor John Stevens built and tested the first American steam locomotive across the Hudson from New York City in Hoboken. Over the next decades, as men like Cornelius Vanderbilt replaced canal and river shipping with railroad lines, American writers and painters began to celebrate a natural world they perceived to be under threat. In 1836, Ralph Waldo Emerson published his essay on Nature; his friend Henry David Thoreau moved to Walden Pond in 1845, publishing $W$ alden in 1854. Just fifteen years later, in 1869, the first transcontinental railroad was completed.

Westward expansion fundamentally transformed the way Americans experienced the natural world and also altered the very shape and texture of that world. The possibilities for industrial and agricultural progress seemed limitless to some, but others worried that hunters, railroads, and new human settlements were threatening whole species and landscapes with destruction (Taylor 2009). Senator Justin Morrill of Vermont, concerned that "the very cheapness of our public lands, and the facility of purchase and transfer, tended to a system of bad farming, [and] strip and waste of soil" (quoted in James 1910: 29), sponsored an 1862 act that donated public lands to the states for the 
establishment of agricultural colleges. In 1872, the first of the National Parks, Yellowstone, was created by President Grant. By the late 1870s, wide swaths of the social and political elite of the post-Civil War United States had become committed to the protection of nature (Taylor 2009).

In New York City, too, the expansion of human settlement had transformed the natural world of Manhattan Island over the course of the century. In 1800, the average population per square mile in New York City (then located entirely in lower Manhattan) was 3,000. By 1900 it was 90,400. (See Table 2.) Street by street, the grid plan laid out by city commissioners on paper in 1811 had been etched with dynamite and pavement into the face of the island. By the 1840s, prominent public voices, most notably poet and editor William Cullen Bryant, were voicing concerns about the steady disappearance of green space in the city (Bryant 1844). In the 1850s, wealthy and powerful citizens successfully mobilized for the creation of an enormous park at the heart of the island. As Central Park's vistas filled in, wealthy families built their Fifth Avenue palaces further and further uptown, and other neighborhoods began to fill with the waves of immigrants arriving through Castle Garden at the foot of Manhattan (Scobey 2002, p. 118). By the close of the century, the population of New York City was nearing two million, and almost all of Manhattan Island had been built up or paved over, except where land had been requisitioned for cemeteries (Demographia 2001). The city grew vertically, too; 300 buildings over nine stories tall were constructed between 1875 and 1900 (Domosh 1987, p. 233; Beckert 2001, p. 253). By 1880, city leaders had begun to worry that even Central Park and Brooklyn's 585-acre Prospect Park, opened in 1867, were inadequate to the needs of the growing populace, and a new effort was launched to establish parks in the less densely populated $23^{\text {rd }}$ and $24^{\text {th }}$ wards of the city, beyond Manhattan Island in the Bronx. The New York Park Association, founded in 1881 by Herald editor John Mullaly, lobbied hard and successfully for the creation of (in the words of the New York Times) "great breathing places 
beyond the Harlem River." 12 As Mullaly later recounted, the successful campaign owed much to the influence of New York's Gilded Age elite:

Whenever the influence of a public man who believed in it could be obtained his co-operation was solicited. In this way men representing large interests in real estate, the Astors, the Belmonts, the Tiffanys, the Claflins, etc., appreciating the effect of the New Parks in the enhancement of values and profiting by the experience in the case of the Central [Park], gave their approval to the movement and united in an earnest appeal to the Mayor, the Legislature and the Governor in favor of the bill (Mullaly 1887, p. 134).

Under pressure of population growth and new theories on public health, a striking shift had taken place in attitudes toward New York's "natural" spaces between the days of Hosack and the rise of the parks movement in the 1880s. The Herald lamented, with the ease of hindsight, the fact that these attitudes had not changed sooner: "It is to-day a cause of regret that the authorities of New York of a half a century ago, did not, while land was cheap, make proper provision for this important and attractive feature of the city." By the end of the 19th century, New York City had a high concentration of people who were unequal in both means and identities, a dramatic transformation from the early Republic. (Images of the island from 1798 and 1902, presented in Figures 3 and 4, display the striking contrasts to which the 19th century's demographic and material changes in Manhattan gave rise. For a timeline of pivotal moments in the national and civic shift from environmental expansiveness to concern, see Figure 5.)

-Table 2 here-Figures 3, 4, \& 5 here-

It was at precisely this moment of burgeoning national alarm about the loss of wild spaces and growing municipal worry about the loss of therapeutic landscapes that Nathaniel Britton chose to launch his campaign, which soon captured the imaginations of citizens concerned about both sorts of natural spaces. For preservationists and conservationists alike, the scientific expeditions and research programs

12 "London has 15 acres and Paris 8 acres to every 1 acre embraced within New-York's park limits. New-York, according to the views of the association, requires a park area of at least 5,000 acres, for she needs to provide not merely for her present population, but for the two millions of persons which she will contain a quarter of a century hence" (New York Times, November 27, 1881, p. 14). 
of the great European botanical gardens offered a model for cataloguing and studying plants and developing plans to protect the threatened flora of the North American continent. For New Yorkers concerned about urban order and health, a beautiful research landscape in the Bronx offered a partial answer to the dilemma of expanding populations and shrinking green spaces. Some of the city's wealthiest citizens drew on their good reputations and considerable finances to support Britton's botanical project. Their wealth, of course, had been derived in large part from the very exploitation of nature that had given rise to the preservationist and conservationist movements. At the same time, their interest in the industrial, medicinal, and agricultural advances promised by research at the new garden emerged out of their own success with earlier such advances.

The state of the material world in which first Hosack and then Britton worked integrally shaped the outcomes of their projects. Active in an environment lush with plant life, Hosack struggled to mobilize support for a plant-focused organization whose scientific goals_advancing American botany and medicine_-remained abstract and unfamiliar to potential funders. By contrast, Britton moved through a densely built environment in which he recognized and harnessed rising concerns about the impoverishment of the natural world. When Britton introduced the organizational form of a researchintensive botanical garden, the materiality of that form had an allure for his contemporaries that was absent in Hosack's time. In sum, it mattered deeply to Hosack's ultimate failure and Britton's success how their contemporaries experienced the natural and built environments in which they lived.

\section{Civic Organization in the Early Republic and the Gilded Age}

Human lives are embedded within social relations with kith and kin, as well as with colleagues and rivals. The array of friendships and affiliations that one has provides both opportunities and resources to pursue various projects. We draw from Stinchcombe (1965) the insight that specific historical moments offer particular arrays of organizational forms. Both Hosack and Britton lived in eras 
marked by numerous membership organizations in which like-minded people routinely came together, yet the character of these associations was stamped by the circumstances of the early Republic and the Gilded Age. To Hosack's fellow New Yorkers, the organizational form of the botanical garden was neither fish nor fowl. By the late 19th century, changes in the way elite New Yorkers understood and organized their philanthropic undertakings had rendered the botanical garden form far more plausible. Hence the options afforded to Hosack and Britton were dictated by the associational structure of their eras.

In the years following the British occupation, New Yorkers worked to rebuild the commercial and cultural life of their city. Voluntary organizations, both old and new, were central to this process. A handful of organizations that had been founded in the Colonial era were refashioned to serve the citizens of the new Republic. This was the case, for example, with King's College, founded in 1754 and reopened in 1784 as Columbia. But it was via a wave of organizational foundings that elite New Yorkers sought most decisively to define the place of their city in the world's youngest democracy. These new enterprises were either member-serving organizations intended to educate and polish their constituents or charitable organizations intended to serve those in need. Both kinds of organizations received charters from the state government in increasing numbers in the post-Revolutionary era. And as Bloch and Lamoreaux argue elsewhere in this volume, New York was among the most active state governments in the early Republic when it came to granting charters for charitable organizations in particular.

We contend that the prevalence and widespread acceptance of these two associational forms hindered Hosack's ability to raise funds for his own novel form, a research-intensive botanical garden. Typical of the member-serving organizations founded in early Republic New York were the Calliopean Society (1788), the New York Academy of Fine Arts (1802), and the New-York Historical Society (1804); Hosack would eventually belong to all three. The Calliopean Society was organized "for the 
express purpose of improving education" (Scott 1933, p. 13). Members, limited to sixty in number, were drawn from New York's educated, professional elite. Early members included William Irving, a fur merchant and future US Representative; Benjamin Moore, an Anglican minister and future president of Columbia College; and Samuel Latham Mitchill, a Columbia medical professor. The library was for members only, supported by quarterly dues. At the club's weekly meetings, members gathered to hear one another read an original composition, recite poetry, give a speech, or engage in a formal debate.

The Academy of Fine Arts was similarly oriented toward the refinement of its members. First suggested by Robert R. Livingston, President Jefferson's minister to France, it was devoted to the appreciation of art, especially classical art. Members' subscriptions went toward the purchase of sculptures and paintings that were displayed in the private meeting-space, discussed, and used for art instruction. Hard on the heels of the Academy of Fine Arts, the New-York Historical Society was founded by some of the same men. The Historical Society's primary purpose was to "discover, procure, and preserve" documents and artifacts relating to the history of the state of New York (Vail 1954, p. 451). Members paid dues in support of the purchase and maintenance of historical materials and in return received permission to peruse the fast-growing collections. It was hoped that such clubs and societies would contribute to the refinement both of their elite members and of the city.

The other primary type of voluntary organization of the era served a different purpose and clientele, although once again, we find some of the same men — and also a number of women—involved in their founding and operations. The Society for the Relief of Distressed Debtors was founded just a few years after the Revolution by a group of businessmen to help residents of the debtors' prison fulfill basic needs for food and clothing (Burrows and Wallace 1999, pp. 381-2). Within a decade, the mission of this charity had expanded to include the distribution of meal tickets to the poor and the establishment of a soup kitchen on land donated by the city council. Its leaders included David Hosack and DeWitt 
Clinton (Bender 1987, p. 50). Hosack would also soon be involved with the New-York Free School Society, founded in 1805 to provide educational opportunities to indigent children.

Our primary and secondary research shows that New York City in the early Republic was home to several dozen of these two types of organizations, the member-serving cultural society and the otherserving charity. David Hosack, who was a founder or member of a half-dozen such societies and charities by the time he launched Elgin, was intimately familiar with these successful models of civic organization. Elgin, however, conformed to neither. Hosack's vision was, instead, of a research and practice-based organization that would advance medicine, botany, and agriculture. Given the unfamiliarity of this model to local audiences, Hosack used his own money to create the garden while seeking funds from Columbia and the state legislature. The challenge he faced, and to which Elgin ultimately succumbed, was that the botanical garden as an organizational form fell between the two available stools. As an organization dedicated to the ancillary training of a small group of impecunious specialists—-medical students—a botanical garden had no natural constituency of well-heeled potential members who would pay subscription fees in order to glean personal and civic benefits. And because medical students did not have the moral claim on the wealthy that impoverished widows, debtors, and street children had, the botanical garden form bore no resemblance to the other-serving charity. Hosack thus envisioned the garden as a specialist organization serving, above all, Columbia, an institution he reasonably believed would have an interest in educating its medical students at a level comparable to London and Edinburgh and exceeding Boston and Philadelphia. Even here, however, he ran into opposition. Some leaders of the academic medical community argued that a botanical garden was not the best use of institutional funds:

The Censors are impressed with the advantages to be derived from the Botanical Garden but from its remote situation and the expenses which must follow, a donation to keep it up would be necessary. The Censors believe the advantages to be derived from the Botanical Garden would be far inferior to that derived from [a] chemical apparatus, an anatomical museum, a medical library..." (quoted in Robbins 1964, p. 81). 
Hosack also believed the garden would serve the large farming community of the state of New York, but here again the constituency was not a natural one for a member-serving, subscription-based society. Farmers were too scattered across the state to visit Elgin in person, and those who were likely to join agricultural associations were already members of local chapters of the New-York State Society for the Promotion of Agriculture, Arts, and Manufactures. Seen in the light of the organizational challenges Hosack faced, the brief life of the Elgin Botanic Garden was a notable accomplishment. Complicating Hosack's efforts further still was the shifting political terrain in which these organizations had been grounded (Neem 2008). In 1800, Jefferson's populist Democratic-Republicans wrested control of the state legislature from the pro-British Federalists; in 1804, after a significant change in its electoral laws, the New York City government also went to the Democratic-Republicans, who preferred to fund charities for the poor over elite educational projects. On December 22, 1807, in what turned out to be a major step on the path to the War of 1812, Congress passed an embargo act outlawing commerce with Great Britain that quickly crippled the economy of New York City and New York State (Taylor 2012, pp. 117-8). Hosack, in short, was addressing his appeals to the city government and state legislature at a time when political developments were running counter to his project. Thus the organizational world into which Hosack brought the unfamiliar form of the botanical garden was not a fertile one. The organizational world of the late 19th century, in contrast, offered tillable soil for Britton's similar effort ninety years after Hosack's.

These propitious changes had begun to take shape decades before Britton launched his campaign for a botanical garden. Eric Hilt argues in this volume that the passage of general acts of incorporation beginning in the Northeast in the second decade of the 19th century led to a gradual loosening of state control over both commercial and charitable initiatives; Lu and Wallis demonstrate a similar process at work in banking. By the middle of the century, as Bloch and Lamoreaux argue, New York legislators in particular had substantially eased restrictions on the creation of charitable 
organizations. In the 1860s, the Civil War catalyzed the organization of large-scale philanthropic efforts across the U.S., offering a testing ground for ideas about the best way to deliver charitable services while also opening new career paths to philanthropically minded men and women (Crocker 2003). Most notably, the US Sanitary Commission, signed into existence by President Lincoln in 1861 and yoking government support to private philanthropy, coordinated an enormous network of volunteers and professionals to provide nursing and other services for the wounded and displaced. Voluntary organizations that survived the Civil War grew in scale and complexity, and many ambitious new philanthropic efforts were launched during Reconstruction (Scott 1993). As DiMaggio (1982) has demonstrated for Boston, some of this post-war philanthropic activity was directed toward securing the boundaries between social classes. By the 1870s, wealthy industrialists, merchants, lawyers, and bankers had joined forces politically and culturally to respond to challenges from an increasingly restive and organized labor force (Beckert 2001, p. 223). In New York City, an important outcome of this class struggle was the creation in the 1870 s and 1880 s of a set of cultural institutions that, as Beckert (2001, p. 267) has argued, "were financially dependent on bourgeois New Yorkers, derived their programmatic ideas from them, and principally catered to the city's economic elite. In turn, they became the focus of bourgeois philanthropy.” In an era when upper-class New Yorkers were increasingly interested in marrying their daughters to titled Europeans, these institutions were modeled on those created and patronized by the aristocracy across the Atlantic.

By the time Britton founded the NYBG, New York's haute bourgeoisie had been working hard to catch up culturally with their European counterparts for more than a decade, starting with the incorporation in 1870 of the Metropolitan Museum of Art. In 1874, the American Museum of Natural History opened its doors, and in 1880, the Metropolitan Museum inaugurated its sumptuous new home on Fifth Avenue, thanks to the patronage of New Yorkers such as William H. Astor, Theodore Roosevelt, J. P. Morgan, and Cornelius Vanderbilt II. In 1883, the Metropolitan Opera was founded to 
accommodate newly wealthy New Yorkers who could not secure boxes at the existing opera house (the Academy of Music), controlled by the elite of Old New York (Kolodin 1966, p. 4). Although New York boasted all of these cultural institutions, it lacked a botanical garden. ${ }^{13}$

Britton skillfully positioned the new garden among this emerging cluster of Gilded Age institutions. An 1891 typescript in his papers makes such a reference explicitly:

The necessary buildings for the purpose should obviously be erected by the city by means of a comparatively small annual interest charge, as was done for the Metropolitan Museum of Art, and for the Museum of Natural History, institutions which are yearly proving themselves to be of vastly greater value to the people than the cost. The buildings for the Botanic Garden should likewise be provided by the city, because private individuals could not be expected to raise money for buildings that would immediately become the property of the city itself (Britton 1891).

The organizational form Britton proposed—a research-based botanical garden funded by a combination of private money and city and state support-was ideally suited to the industrialists whose patronage he needed. Vilified by the press for their labor and environmental practices, these men wholeheartedly embraced the opportunity to support an organization dedicated to serving the public good through research, teaching, and recreation. Britton thus benefited from, and actively capitalized on, the transformation of the civic order under way in Gilded Age New York, showing a capacity for fundraising that would be the envy of any university president or nonprofit director today. Britton inspired in his patrons a deep confidence in his talents—-so much so, in fact, that Carnegie himself eventually tried to hire him away from the botanical garden (Rusby 1934, p. 110). Carnegie, Morgan, Rockefeller, and Vanderbilt each pledged $\$ 25,000$ of their own money toward the requisite $\$ 250,000$.

${ }^{13}$ In 1856, as Central Park was initially being planned, the financier Augustus Belmont sought to establish a privately run botanical garden there, noting that "a great many much smaller places than New York, such as Brussels, Antwerp, etc. have similar establishments without any aid of Government" (quoted in Rosenzweig and Blackmar 1992, p. 340). In 1857, the chief engineer for Central Park, Egbert Viele, was optimistic about including a botanical garden (New York Times, January 20,1857, p. 3). A number of the plans submitted for the 1858 park design competition contained botanical gardens, but the winning plan by Frederick Law Olmsted and Calvert Vaux did not, and none was built. In 1875, the president of the city's College of Pharmacy submitted a petition on behalf of various medical and pharmacological colleges and societies for the "establishment of a botanical garden in one of the parks of this city" (New York Times, April 15, 1875, p. 8). The report was forwarded to Olmsted, superintendent and architect-in-chief of Central Park since 1858, but the campaign for a botanical garden still bore no fruit. 
Britton also set up an administrative structure for the garden that would keep these men involved. It included a board of managers, six scientific directors, and two ex-officio members (the mayor of New York and the city's Commissioner of Parks). Carnegie, Morgan, and Vanderbilt each accepted a formal position in the new garden's managerial ranks: Vanderbilt served as the garden's first president, Carnegie as its first vice president, and Morgan as its first treasurer (Mickulas 2007, p. 63). An 1893 letter to Britton from one of the garden managers, Charles Cox, conveys the extent to which Vanderbilt and Morgan engaged themselves in fundraising:

My Dear Dr. Britton: ...Mr. C Vanderbilt has started to get on paper the subscriptions to the Botanical Garden that have been promised in sums less than $\$ 25,000$. His idea is not to have it generally known that these small subscriptions are being taken, but yet to get them down in black and white as fast as he hears of them, and to quietly obtain new ones without prejudicing Mr. Morgan's scheme for completing the larger list. He has also undertaken to poke Mr. Morgan up a little. ${ }^{14}$

The vast fortunes by which the United States had become a much more unequal society thus opened the door for a scale of support unimaginable from private citizens in the early Republic (Zunz 2014). It might be tempting to see the Gilded Age fortunes as apples ripe for the picking, but this is not a story of mere availability of great wealth. These fortunes had to be diverted away from conspicuous consumption to public purposes. Britton showed great aptitude for this re-purposing, inserting a significant, sustained research component into his plan for the garden and tying it to doctoral studies at Columbia University, two aims quite distant from the interests of his industrialist supporters.

To realize their vision of New York as the "chief city of the New World," Carnegie, Morgan, Vanderbilt, Rockefeller, and their fellow elites needed cultural and scientific institutions on a par with those sustained by royal patronage in Europe. These elites also needed talented experts such as Britton to organize and administer their complex philanthropic organizations. Here, too, a seismic shift had taken place between Hosack's time and Britton's, which we summarize in Table 3. During the early years of the Republic, a typical New York civic organization in the arts and sciences was organized, funded,

${ }^{14}$ Charles F. Cox to Nathaniel Britton, March 8, 1893, Addison Brown Papers, Mertz Library, NYBG. 
and given its mission and content by the selfsame individuals. By the Gilded Age, this knot of roles had been pulled apart into separate strands: Carnegie was the philanthropist, but Britton was the expert. Philanthropic patronage enabled nonprofit organizations, and a new class of professional experts became their managers (DiMaggio 1991). A sharp rise, beginning in the 1880s, in the number of learned societies founded in the United States signaled the advent of that new class of experts, a process we analyze in the next section. (For an overview of the transformation of associational life from small member- and other-serving organizations to expert-managed, large-scale institutions, see Figure 6.)

-Table 3 here-

-Figure 6 here-

\section{From Polymaths to Professionals: Changes in the Organization of 19th-Century Knowledge}

The status and power of experts in the late 19th century contrast sharply with the organization of knowledge in Hosack's era. The pursuit of knowledge in early New York-botanical or otherwisewas largely the domain of polymaths such as Hosack who pursued a calling while exploring many fields in a variety of formal and informal settings. Hosack himself was involved not only with the study of medicine, his official profession, but also botany, history, literature, manufacturing, agriculture, the visual arts, and natural history. This range of interests was the rule in his circles, rather than the exception; indeed, some of his contemporaries outstripped him in the breadth of their pursuits. ${ }^{15}$

In New York City in the early Republic, botany was a rare pursuit. At best, it was among the most neglected of the many artistic and scientific topics that a cultivated "gentleman" might study; few colleges anywhere in the U.S. had dedicated professorships in botany (Rudolph 1996, p. 661). American

\footnotetext{
15 As but one illustration, Samuel Latham Mitchill, a prominent New York doctor who went on to co-found the Rutgers Medical School, held professorships in natural history, chemistry, agriculture, botany, and medicineand was an expert in ichthyology (Baatz 1990, p. 10). He was also a founder of both the NYSSPAAM and the Lyceum of Natural History of New York. He was a member of the New-York Historical Society, the Free School Society, the Literary and Philosophical Society, the New-York Horticultural Society, the New-York Hospital, the Calliopean Society, and the Friendly Club (Aberbach 1988). He also served as a president of the abolitionist Manumission Society and as a US Senator from New York.
} 
botany was almost entirely an amateur endeavor. By the time Britton was working to found the NYBG, the conditions in which scientific knowledge was pursued had changed dramatically. In the early 19th century, the fields of law and medicine had seen an increase in expertise via the introduction of educational reforms, the establishment of board exams and licenses, and the diffusion of local, state, and national professional associations (Abbott 1988). The expansion of access by the mid-19th century to organizational settings in which such work could be coordinated and pursued helped accelerate these developments. In the arts and sciences, the social production of the disciplinary "expert" took place more slowly, but by the 1870s, polymaths such as Britton's teacher John Strong Newberry-physician, geologist, botanist, and president of the multidisciplinary Lyceum of Natural History—were on the verge of extinction. Increasingly, academic scientists were professionalizing extant organizations such as the Lyceum or founding new ones that distanced themselves from the applied emphasis of amateur scientific societies and instead embraced the pursuit of science for its own sake. Scientists in many different fields also founded increasing numbers of specialized journals for the publication of disciplinebased research. In New York botanical circles, this process began in 1870, with the Torrey Botanical Club's launch at Columbia of an academic journal dedicated to botany. In this setting, the first students, including Nathaniel Britton, were formed as professional botanists—rather than in the prior, broader category of natural historian. In the process, these scientists were effectively "restricting the rank of specialist to academics" (Sloan 1980, p. 48).

The trend toward specialization in the sciences can be read in Britton's own organizational affiliations. Unlike Hosack, who practiced his chosen profession of medicine while engaging with many other fields, Britton focused exclusively on academic science in general and botany in particular. As his career progressed, the organizations with which he was involved grew in scope and complexity. Britton was either a founder or an early member of the Torrey Botanical Club, the New York Academy of Sciences, the Natural Science Association of Staten Island, the Scientific Alliance of New York, the 
Botanical Society of America, and the American Association for the Advancement of Science, which became the preeminent scientific association in the U.S. Through these organizations, he played a central role in forging the profession of scientific botany. His engagement with the production of botanical expertise gave him a platform from which to assert the scientific importance of botany for its own sake and thus an additional argument for the importance of a world-class botanical garden. ${ }^{16}$

At the same time, the transformation of Columbia from the struggling, indebted college of the early Republic into the wealthy university of the late 19th century gave Britton access to resources that were simply nonexistent in Hosack's day. In the early Republic, Columbia occupied a single building at Park Place, comprised an "arts" faculty and a medical faculty, and graduated just sixteen students in 1800. The college was often in the red and asked for repeated loans from the state legislature (McCaughey 2003). After the Civil War, however, national trends toward credentialing in the arts, sciences, and professions increased the demand for advanced degrees, driving up enrollments and tuition income. The first American PhD was granted by Yale University in 1861. Between 1861 and 1869, twelve PhDs were granted; between 1870 and 1880, the number jumped to $281 .{ }^{17}$ This increased demand dovetailed with trends toward specialization among academics, and by 1893, Columbia was composed of not only its original college and school of medicine but also half a dozen graduate schools. ${ }^{18}$ Its endowment had skyrocketed as well, thanks in part to rent from its Manhattan real

\footnotetext{
16 One might be tempted to conclude that Hosack had trouble establishing New York's first botanical garden because he was a gentleman dabbler, whereas Britton, who succeeded, was an expert and a professional. We have shown that Hosack was indeed active in many fields and organizations, whereas Britton focused intensively on botany throughout his career. Did this intense specialization give Britton an advantage over Hosack that could explain the former's success and the latter's difficulty? Such an explanation would depend on the retrospective projection of contemporary values onto a historically distant social context. From the vantage point of the present, the expert Britton resembles our picture of organizational success rather more closely than the experimenting Hosack. In the early Republic, however, men such as Hosack, along with his contemporaries Jefferson, Clinton, and Livingston, were politically and organizationally effective precisely because of - not in spite of - their wide-ranging interests and accomplishments, which were the source not only of knowledge and skills but also of great social prestige and many contacts. In the cultural and scientific milieu of the early 19th century, breadth and variety of pursuits were assets, not liabilities.

17 Pierson 1983, p. 22; Gartner et al. 2006.

18 http://beatl.barnard.columbia.edu/stand_columbia/TimelineECU.htm. Accessed January 3, 2013.
} 
estate-including the former site of the Elgin Botanic Garden, donated to Columbia by the state in

1814. In the 1890s, Seth Low presided over the construction of an expansive new campus in northern

Manhattan. (Table 4 depicts the changes in the organization of science and the transformation of

Columbia from the early to late 19th century.)

-Table 4 here-

Columbia's wealth in Britton's era contrasted sharply with the impoverished college of Hosack's day. Hosack's Columbia did not manage to make even the first of the annual payments of 300 pounds they had promised him for the new botanical garden in 1797 (Robbins 1964). Yet it was not at all inevitable that the Gilded Age administrators of Columbia would use their funds to support a botanical garden. Thanks to Britton's deep involvement in professional botany and his authority as a scientific expert, he occupied a position from which he both drove the process of specialization and reaped its academic and organizational rewards. For Britton, the primary reward was Columbia’s financial, administrative, and reputational support in the creation of the NYBG. ${ }^{19}$ Columbia's growth was mirrored nationally, as the academy, and with it doctoral education, expanded markedly. (Figure 7 highlights the professionalization of science and botany and documents the sharp increase in academic credentialing that began in the 1870s.)

-Figure 7 here-

${ }^{19}$ We noted earlier that our case comparison differs from traditional Mill-inspired methods. To throw into relief the differences between distinct macro-historical conditions, we have chosen two efforts to introduce the same form to the same geographic region. This means that we face a version of an analytical challenge familiar to comparative-historical researchers: the possibility of actors' learning from one case to another, in a manner that muddies the causal relations. For many comparative-historical researchers, this concern takes the form of possible diffusion across national boundaries; for our two cases, diffusion is temporal rather than geographical. Did Britton succeed because he learned from Hosack's mistakes? Britton, as a member of the Torrey Botanical Club, founded by John Torrey, who had studied with Hosack, would likely have learned that Hosack had tried and failed to establish a botanical garden in New York ninety years earlier. Nonetheless, the historical context had changed so dramatically that Hosack's limitations, even if they had been clear to Britton, would have been irrelevant. Politically, culturally, and organizationally, Britton's world was fundamentally different. The steps Britton took were skilled in his context and taken toward that context, rather than oriented away from Hosack's project. Moreover, we find no archival evidence that Britton was a beneficiary of a "second mover" advantage, in which he capitalized on Hosack's earlier failure to gain traction for the Elgin Botanic Garden. 


\section{The Propagation of an Organizational Form}

Britton's success in establishing the New York Botanical Garden is evident in its 125 years of scientific and aesthetic achievements. For a new form to transform the organizational landscape, however, it must take on a life of its own, propagating beyond the original into new geographical and cultural domains. In creating the NYBG, Britton touched many cities far beyond the boundaries of New York, as his organization inspired a wave of garden foundings across the country. This new form also had ramifications outside the world of botany. The model of an expert-led, privately financed, publicly oriented organization committed to cultivating expert knowledge gave impetus to the founding of such organizations in many other domains of service and knowledge.

The celebration of New York's world-class botanical garden in the national press as well as via social networks of wealthy citizens and professional networks of botanists and horticulturists led to a proliferation of botanical gardens across the U.S. ${ }^{20}$ In 1895, covering the founding of the NYBG from the other end of the continent, the Portland Oregonian ambitiously predicted that "the New World will show in 10 years from now as many botanical gardens as the Old" (Oregonian, December 27, 1895, p. 6). The prestige of the New York project and its leaders helped forge an association between botanical gardens and strong civic cultures. Wealthy civic leaders in other communities took their cue from the Manhattan elites who had successfully advanced the idea that an important city—whether American or European-included a botanical garden among its major institutions. Soon after Britton launched his campaign in New York, Pittsburgh's Henry Phipps—Andrew Carnegie’s boyhood friend and longtime business partner — made a gift to his fellow citizens of a small botanical garden, hiring the same firm as

\footnotetext{
${ }^{20}$ For national coverage of the first years of the NYBG, see, for example, "Botanical garden proposed," Oregonian, February 22, 1891; “Topics in New York: A great display of fine orchids," Sun (Baltimore), March 3 , 1891; "New York," Duluth News-Tribune, May 2, 1891; "Topics in New York: How public spirit increases and the city is improving," Sun, July 21, 1893; “A Botanical Garden: New enterprise full of promise for New York City's welfare," Oregonian, August 15, 1895; “New York’s Botanical Garden,” Kansas City Star, September 1, 1895.
} 
Britton (Lord \& Burnham Co.) to design the conservatory. In 1895, civic leaders in Buffalo established a botanical garden that also included a Lord \& Burnham conservatory; the same year saw a similar establishment in Columbus. In 1896, a movement was begun for a garden in Baltimore (Sun, May 14, 1896, p. 1). In 1904, Detroit opened a botanical garden on Belle Isle, an island in the Detroit River that had been landscaped in the 1880s by Frederick Law Olmsted. In 1910, Brooklyn, which had been an independent city until 1898 and whose elites long sought to establish an array of cultural and scientific institutions to rival Manhattan, opened its own botanical garden (Brooklyn Institute of Arts and Sciences 1909). As the Brooklyn Botanic Garden was being organized during the first decade of the 20th century, its creators turned repeatedly to Nathaniel Britton for plant specimens to help build their new collections as well as for administrative and botanical advice. More distant cities, too, soon saw the creation of gardens through partnerships between wealthy citizens and botanical experts, with San Francisco opening one in 1926 and Miami in 1938. In short, the NYBG helped define a major early 20th-century American city as a place where it was de rigueur to maintain not only an art museum, a theater, a symphony, and an opera house, but also a botanical garden.

The establishment of the NYBG also affected the contours of associational and professional life closer to home. If Britton and his wealthy backers benefited from the legitimacy of partnerships between elite funders and semi-professional directors that emerged in the 1870s and 1880s with the founding of the American Museum of Natural History, the Metropolitan Museum of Art, and the Metropolitan Opera, the highly public success of the NYBG added strength and visibility to this professional model. The earliest of these Gilded Age institutions were directed by polymaths, whereas many of the civic organizations founded after the NYBG were led by specialists trained in academic settings. ${ }^{21}$ The business leaders who founded the Brooklyn Botanic Garden in 1910 recruited Dr.

${ }^{21}$ The first director of the American Museum of Natural History, John David Wolfe, was a retired businessman who dedicated his later years to philanthropic activities (Duyckinck 1872). The first director of the Metropolitan 
Charles Stuart Gager, a professor of botany at the University of Missouri, as its first director (Svenson 1944, pp. 1-2). A decade later, the Museum of Modern Art was established with financial backing from Mrs. John D. Rockefeller, Jr., and two other arts patrons; they chose as its founding director a Wellesley art history professor, Alfred H. Barr, Jr. (Chernow 1999, p. 647). In 1907, Margaret Olivia Slocum Sage created the Russell Sage Foundation to improve living conditions for the poor, appointing lawyer John M. Glenn as its first director (American Sociological Review 1950, p. 680). The rise in status and power of professional experts in the late 19th and early 20th century was perhaps most fully embodied by the Social Science Research Council, founded in New York City in 1923. Funded by the Rockefellers and organized by Charles E. Merriam, a Chicago professor who was president of the American Political Science Association, the SSRC brought together representatives from the leading social scientific professional associations - the American Economic Association, the American Historical Association, the American Psychological Association, the American Sociological Society, and the American Statistical Association — to foster expert knowledge for the improvement of public policy.

These organizations represented a new era in American philanthropy, one in which academically trained experts became the mediators between public service and private trust. Before the Civil War, philanthropic activity in the U.S. had been overseen largely by men whose true careers lay in other domains. By century's end, the accumulation of enormous fortunes by men such as Carnegie, Morgan, Rockefeller, and Vanderbilt—whose religious leanings and reputational anxieties inclined them toward public largesse- - had opened the floodgates for giving on a scale previously unseen in the States (Zunz 2014). As these tycoons sought advice on the disbursement of their money, men of learning and vision stepped forward to help them create organizational vehicles through which to serve the public good. City and state officials offered financial and regulatory support for such philanthropic efforts when they saw in them opportunities to tackle problems attendant on urban growth and inequality.

Museum of Art, Luigi Palma di Cesnola, was a soldier and diplomat who brought antiquities back to New York from a posting to Cyprus (Peterson 1986, p. 162). 
Nathaniel Britton's success in fusing these disparate sources of support to create the NYBG, with himself as academic expert at the helm, gave force and substance to the spillover of a researchbased garden into related professional domains. As further illustration of this reshaping of civic life, two organizations founded by Andrew Carnegie in the years following his involvement with the NYBGthe Carnegie Foundation (1906) and the Carnegie Corporation (1911)_took as their mission the production of expert knowledge in education, economics, the law, and a range of other disciplines (Lagemann 1989). Thus Britton's success with his botanical garden reverberated not only across the country but also back into the academic world from which he had come and out into the wider world of professional philanthropy. Professional expertise was now sought not only inside the walls of the academy; professional renown became attached to the exercise of that specialized knowledge in the wider public sphere. A new cadre of elite academics was born, men who could cross among the elite worlds of the university, foundations, and influential nonprofit organizations (DiMaggio 1991).

\section{DISCUSSION}

In this section, we show that the concept of poisedness offers new analytic purchase for identifying those moments when the political and economic context and the efforts of enterprising individuals combine to create possibilities for new forms. Our first point concerns the shift from project- and population-level analysis to multi-domain, macro-historical analysis. We began our case comparison with concepts that have often been used in isolation from a specific place and time. We set our analysis of the emergence of a new organizational form squarely in the midst of historical processes unfolding in 19th-century America. This approach leads us to think rather differently about the concepts of project, biography, template, and skill. Given their considerable abilities, Hosack and Britton might well have had equal chances at success. But rather than seeing the founding of two botanical gardens through the eyes of two gifted men, we examine their efforts in the context of the rise of environmental 
and preservation movements and the almost complete urbanization of Manhattan Island over the course of the 19th century. We have shown that a botanical garden-an organization that would physically protect a piece of land from urban development and make it available for scientific research and aesthetic enjoyment—made sense by the century's end in ways that were unthinkable at its beginning.

But it is not only the organizational template of a garden that had different meanings; the skills of David Hosack and Nathaniel Britton were perceived differently as well. Hosack was the preeminent doctor of New York City, concerned with matters of public health and the training of the new cadre of young physicians, worried about how a young republic would survive without colonial resources and access to knowledge. Britton was a university professor, adept at research, marshaling evidence, organizing meetings, and building professional societies. His professional skills would have found little traction in 1801; indeed, a man of university science did not exist then. The early 19th century was an era in which breadth and variety of pursuits were the order of the day.

Thus the impact of macro-level structures on the success of organizational projects does not depend solely on the knowledge or mobilization of those processes by individuals. To be sure, savvy innovators often recognize the way historical winds are blowing. Britton clearly saw the power of invoking the language of scientific expertise, yet he held the status of expert in botany not because he had sought it in order to see his project through, but because he matured in an intellectual era in which academic specialization in a branch of the natural sciences brought this esteem. Hosack had no such options. His notable biography included being the attending doctor at the duel of two of the most famous men in America. He could correspond with President Jefferson and converse with New York's most influential citizens, but he could not fashion a compelling case for a research-based garden at a time when land was plentiful. Transformations unfolded over the 19th century to produce new categories of persons (the expert, the preservationist, and the philanthropist) and different ways of thinking about the uses of a botanical garden (scientific progress, education of the public, enjoyment of 
a natural world that was disappearing). Britton and his botanical garden were the beneficiaries of these new categories of actor and thought.

To make the concept of poisedness empirically tractable, one needs to consider not only the presence of structural availability for an organizational innovation, but also its degree and duration. Different social settings will display greater or lesser poisedness for the emergence of particular organizational forms; at the same time, the poisedness of a given setting is temporally bounded and can be thought of as a window that opens for a time and then closes again. In our case comparison, an initial examination using the concepts of project, biography, template, and skill drew our attention to three decisive macro-level processes with meso-level reverberations: changes in the material environment, the character of civil society, and the organization of expert knowledge and intellectual life. Individually, as we have shown, each of these processes supported Britton's efforts to establish a botanical garden. These three processes also intertwined supportively with one another, thus affording Britton an exceptionally strong platform for the kind of organization he envisioned.

The transformation of the natural world during the 19th century at the hands of industrialists and real estate tycoons, many of whom chose to reside in New York, produced fortunes on a scale unimaginable in Hosack's day and at the disposal of private citizens. The concomitantly increasing complexity of private industrial, commercial, and financial operations fostered the emergence of a managerial class (Chandler 1977). At the same time, specialization and professionalization in the arts and sciences were giving rise to a cadre of experts via graduate training and credentialing. "[C]apital-owning New Yorkers admitted experts and managers to their social networks and cultural institutions because these networks and institutions themselves were central to their economic projects and could not exclude those who played important roles in running factories, merchant houses, and banks" (Beckert 2001, p. 254). 
These experts would be critical to the creation and management of Gilded Age scientific and cultural institutions. Exposed through extensive travel to European history and habits, wealthy New Yorkers sought to create not only private surroundings but also public institutions on a par with those bankrolled by royalty in Europe. Some of these institutions responded to meet concerns about wholesome and edifying relaxation opportunities for the leisured and working classes alike. And in a related process, the heavy build-up of Manhattan triggered worries about hygiene and aesthetics; the New York Park Association was populated by a number of the same industrialists who had joined together to create the American Museum of Natural History, the Metropolitan Museum of Art, Carnegie Hall, and other Gilded Age institutions. Finally, the development of Manhattan had also been the source of some of Columbia's good financial fortune, via its many property leases, in the second half of the 19th century. The expansion of Columbia from a small college into a complex university, in turn, supported Britton in his project both reputationally and financially.

The concatenation of these three lines of development, illustrated in Table 5 , meant that by approximately 1880, the previously separate domains of environmental consciousness, public-private initiatives, and academic science could be drawn together to fashion a vision for the NYBG. The ramifications of these cross-field effects opened new possibilities, unanticipated in any one domain alone (Mora 2014). Thus the interlocking changes in the material environment, in modes of civic organization and philanthropy, and in the organization of expert knowledge coalesced in ways that strengthened the odds of Britton's success and, in turn, influenced ambitious civic elites across the country to establish botanical gardens in their own cities. Put sharply, Britton's project benefited from a very high degree of poisedness in his social and material context. It is for this reason above all that Britton was successful compared to Hosack, who did not have the winds of historical change at his back.

-Table 5 here- 
The poisedness of social structures profoundly shapes the chances of entrepreneurial projects, regardless how skilled the individual innovator. The structural characteristics we have analyzed are essential to explaining the divergent outcomes of these two efforts to create a botanical garden because they reveal two starkly different moments of poisedness. Conceptually speaking, then, poisedness captures the strength of concatenation among macro- and meso-level processes, both laterally and vertically, vis-à-vis micro-level efforts at organizational innovation. The concept of poisedness also emphasizes how "evolvable" these relations are. By this we mean whether lateral and vertical spillovers to other geographic locales and related lines of work offer amplification for individual efforts at entrepreneurship.

A significant advantage of our approach is that it avoids the pitfalls of conflating instances of individual success with the structural availability that enabled their realization. Organization scholars have long recognized the challenges of studying failure and absence (Hannan and Freeman 1986; McAdam and Boudet 2012; Powell, Packalen, and Whittington 2012). Organizational failures provide critical information for scholars seeking to understand the sources of success, yet failed efforts to found a new organization often yield limited records and therefore hinder data collection. Even more challenging is the study of organizational absence. When and why are specific kinds of organizations not being founded—or even conceived of at all? Answering these difficult questions is critical to the project of explaining how skilled actors do, on occasion, produce profound and wide-ranging organizational innovation.

Our analysis of 19th-century New York demonstrates that conditions were not poised for the establishment and spread of a research- and teaching-intensive botanical garden in the United States until approximately 1880. Our overarching argument is not purely a structural one, however. Poisedness does not produce innovation absent individual effort. Britton's ultimate and resounding success in introducing a new organizational form was by no means inevitable. He worked tirelessly for many years 
as he developed and framed his organizational template; met with wealthy, public-spirited citizens such as Carnegie, Morgan, and Vanderbilt; pushed Columbia to partner with the garden; wrote opinion pieces and gave speeches about the need for a garden at clubs and associations; lobbied the city and state governments for land, subsidies, and building permits; announced requests for proposals; allocated contracts; and oversaw the landscaping and planting of the grounds. In short, Britton capitalized on the poisedness of his social setting with dogged persistence and consummate skill, in a manner akin to the entrepreneurs and activists documented by the literature on institutional entrepreneurship and social movements. We find these literatures lacking, however, with respect to the origins of those actors who are able to realize the potential inherent in particular social settings.

Scholars of institutional entrepreneurship and social movements have pointed out that individuals positioned at the intersection between organizational fields are most likely to recognize opportunities for organizational innovation. We agree there is ample evidence that positioning is important. Yet although attempts at organizational innovation are undertaken all the time, such efforts rarely succeed, and even more infrequently do they alter activities outside of their local context. We can see as much in David Hosack's valiant efforts to introduce a new organizational form, where in spite of his efforts he ended up reinforcing the organizational world he wished to change. One might say that the window of opportunity was closed to him; indeed, the archival evidence strongly suggests that no one could have realized his vision for New York City at that point in its history. By the last quarter of the 19th century, however, Manhattan was no longer bucolic; it was crowded and congested, as the data on population density illustrate. New kinds of public-private initiatives were being created, and abundant resources were available for creating these organizations. The window of opportunity was open.

Could anyone have recognized and realized this opportunity? We think not. To be sure, the linkages between material, organizational, and professional conditions afforded a scaffolding that supported the emergence of new organizational models. But for these new organizations to grow in 
scale and influence they needed people at their helm who could fuse private wealth with public-serving goals. The key to combining private money with public interests was the ability to harness the impartiality of professional expertise. Professional learned societies were one such domain of judgment, and they were populated by a growing number of experts in the form of newly minted PhDs. And in the years after the Civil War, the organization of social services and of educational and cultural activities passed from churches and almshouses to formal, bureaucratically structured public and nonprofit organizations. Philanthropy as a large-scale activity rose to unprecedented heights in the last two decades of the century when men such as Carnegie, Rockefeller, and others began dispersing their vast fortunes.

In crossing the domains of wealth, culture, and science, innovations were not simply carried from one realm to another as a form of export. New opportunities were created and amplified by such crossings. This transformed context made possible novel forms of organizing, but it also produced a new kind of actor: the scientific expert and manager. Nathaniel Britton was among those at the forefront of the growth of university-based science, and as a professor of botany at Columbia, he was a leader in a new field that was beginning to coalesce in academic departments and professional associations by the 1880s. Thus the very same structural processes that produced the strong poisedness of late 19th-century New York for the botanical garden form also produced the managerial and botanical expert Nathaniel Britton, who was by disposition and knowledge highly equipped to realize that potential.

\section{CONCLUSION}

In his classic essay, Stinchcombe (1965, p. 150) suggested a host of factors-“"(a) general literacy and specialized advanced schooling; (b) urbanization; (c) a money economy; (d) political revolution; (e) a dense social life, including an already rich organizational life" — that catalyze organization-building. In our two cases, David Hosack toiled in a young democracy formed by political revolution, with a 
mercantile economy and general literacy, but Nathaniel Britton worked a different soil, rich with a diverse organizational life and a growing specialization of knowledge, in a dense urban setting. The dominant associational form of the late 19th century was one in which funders, managers, and beneficiaries were separate; the expert professor, Britton, was a welcome intermediary who could cross these milieux. The donor-funded, expert-managed garden meshed closely with other Gilded Age scientific and cultural institutions bankrolled by private donors, managed by experts, and open to the New York City public. The organizational landscape was sloped in Britton's favor. His expertise was a sought-after commodity, which immunized him from the social and economic cleavages of his day. In contrast, Hosack's Elgin Botanic Garden was a victim of cultural and geopolitical struggles.

These two cases demonstrate that novelty arises from feedback among multiple social networks across material, organizational, and intellectual domains. Poisedness concerns not just enabling conditions or opportunity structures of the sort that Stinchcombe so usefully identified, but the concatenation of social, political, and economic forces that make new forms possible. The emergence of new categories of people and organization in our historical analysis was the result of new possibilities at the micro-, meso-, and macro-levels, which expanded the opportunities available at the end of the 19th century. This poisedness had fundamentally different ramifications not only for David Hosack and Nathanial Britton, but for New York City in the 19th century as well.

We urge caution in how the idea of poisedness is used. It should not be thought of crudely as implying fitness or timely alignment. Social structures indeed both constrain and generate options, but there are always spaces in which struggles and oppositional framings can occur. Nor are we claiming simply that history and context matter. To be analytically meaningful, research must specify the contours and limitations of context. Without the discipline of a deductive framework, multi-level historical analyses can become ad hoc. Our contextual refinement, which enabled us to argue that Britton's world was more poised than Hosack's, is two-fold. First, within the context of New York City in the 19th 
century, attitudes about the material world, appropriate beneficiaries of services, and the uses of expertise were critical in shaping responses to proposals for new types of organizations. Second, in the first decades of the 19th century, these elements all worked against David Hosack, but by century's end, these elements began to buttress one another, creating self-reinforcing linkages that enabled the emergence of new types of actors, social relationships, and organizations. When we see such overlays of the social-structural landscape, we find cascading moments of poisedness of the type we have analyzed here, in which circumstances are receptive to new forms of organization. 


\section{REFERENCES}

Abbott, Andrew. 1988. The System of Professions: An Essay on the Division of Expert Labor. Chicago:

University of Chicago Press.

-----. 1995. "Things of Boundaries." Social Research 62 (4): 857-82.

----. 2001. Time Matters: On Theory and Method. Chicago: University of Chicago Press.

Aberbach, Alan David. 1988. In Search of an American Identity: Samuel Latham Mitchill, Jeffersonian Nationalist. New York: Peter Lang.

Aldrich, Howard E. 2009. "Lost in Space, Out of Time: Why and How We Should Study Organizations Comparatively." Research in the Sociology of Organizations 26:21-44.

American Sociological Review. 1950. "John Mark Glenn, 1858-1950.” American Sociological Review 15 (5): 680.

Arthur, Brian. 1994. Increasing Returns and Path Dependence in the Economy. Ann Arbor, Mich.: University of Michigan Press.

Baatz, Simon. 1990. Knowledge, Culture, and Science in the Metropolis: The New York Academy of Sciences, $1817-$ 1970. New York: New York Academy of Sciences.

Barkey, Karen. 2008. Empire of Difference: The Ottomans in Comparative Perspective. New York: Cambridge University Press.

Baron, James N., Michael T. Hannan, and M. Diane Burton. 2001. "Labor Pains: Change in Organizational Models and Employee Turnover in Young, High-Tech Firms." American Journal of Sociology 106 (4): 960-1012.

Battilana, Julie, Bernard Leca, and Eva Boxenbaum. 2009. "How Actors Change Institutions: Towards a Theory of Institutional Entrepreneurship." Academy of Management Annals 3 (1): 65-107.

Beckert, Jens. 1999. “Agency, Entrepreneurs, and Institutional Change: The Role of Strategic Choice and Institutionalized Practices in Organizations.” Organization Studies 20:777-99.

----. 2010. "Institutional Isomorphism Revisited: Convergence and Divergence in Institutional Change." Sociological Theory 28 (2): 150-66.

Beckert, Sven. 2001. The Moneyed Metropolis: New York City and the Consolidation of the American Bourgeoisie, 1850-1896. Cambridge: Cambridge University Press.

Bender, Thomas. 1987. New York Intellect: A History of Intellectual Life in New York City from 1750 to the Beginnings of Our Own Time. Baltimore: Johns Hopkins University Press.

Benford, Robert D., and David A. Snow. 2000. "Framing Processes and Social Movements: An Overview and Assessment." Annual Review of Sociology 26:611-39.

Britton, Nathaniel Lord. 1891. [Typescript, no title.] Mertz Library, New York Botanical Garden.

----. 1896. “Botanical Gardens: Origin and Development.” Science 4 (88): 284-93.

Brockway, Lucile H. (1979) 2002. Science and Colonial Expansion: The Role of the British Royal Botanic Gardens. New Haven, Conn.: Yale University Press.

Brooklyn Institute of Arts and Sciences. 1909. Prospectus. New York.

Bryant, William Cullen. 1844. “A New Public Park.” New-York Evening Post, July 3, 1844.

Burke, Kenneth. 1935. Permanence and Change: An Anatomy of Purpose. New York: New Republic.

Burrows, Edwin G., and Mike Wallace. 1999. Gotham. New York: Oxford University Press.

Burton, M. Diane, and Christine M. Beckman. 2007. "Leaving a Legacy: Position Imprints and Successor Turnover in Young Firms." American Sociological Review 72 (2): 239-66. 
Burton, M. Diane, Jesper B. Sørensen, and Christine M. Beckman. 2002. "Coming from Good Stock: Career Histories and New Venture Formation.” Research in the Sociology of Organizations 19:229-62.

Carroll, Glenn R., and Anand Swaminathan. 2000. "Why the Micro-Brewery Movement? Organizational Dynamics of Resource Partitioning in the U.S. Brewing Industry." American Journal of Sociology 106 (3): 715-62.

Carroll, Glenn R., and Michael T. Hannan. 2004. The Demography of Corporations and Industries. Princeton, N.J.: Princeton University Press.

Chandler, Alfred D., Jr. 1977. The Visible Hand: The Managerial Revolution in American Business. Cambridge, Mass.: Harvard University Press.

Chernow, Ron. 1999. Titan: The Life of John D. Rockefeller, Sr. New York: Vintage.

----. 2004. Alexander Hamilton. New York: Penguin.

Clemens, Elisabeth S. 1993. “Organizational Repertoires and Institutional Change: Women's Groups and the Transformation of U.S. Politics, 1890-1920." American Journal of Sociology 98 (4): 755-98.

----. 1997. The People's Lobby: Organizational Innovation and the Rise of Interest Group Politics in the United States, 1890-1925. Chicago: University of Chicago Press.

----. 2007. "Retrospective: Formative Action and Second Acts." Pp. 363-77 in Formative Acts: American Politics in the Making, edited by Stephen Skowronek and Matthew Glassman. Philadelphia: University of Pennsylvania Press.

Coleman, James S. 1986. "Social Theory, Social Research, and a Theory of Action." American Journal of Sociology 91 (6): 1309-1335.

College of Physicians and Surgeons. 1812. The Exposition of the Transactions of the College of Physicians and Surgeons. New York.

Collins, Randall. 1981. “On the Microfoundations of Macrosociology.” American Journal of Sociology 86(5): 984-1014.

Conn, Andrew R., Katya Scheinberg, and Luis N. Vicente. 2005. "Geometry of Sample Sets in Derivative Free Optimization." IMA Journal of Numerical Analysis 28 (4): 721-48.

Crocker, Ruth. 2003. "From Gift to Foundation: The Philanthropic Lives of Mrs. Russell Sage.” Pp. 199-215 in Charity, Philanthropy, and Civility in American History, edited by Lawrence J. Friedman and Mark D. McGarvie. Cambridge: Cambridge University Press.

Demographia. 2001. "New York (Manhattan) Wards: Population \& Density 1800-1910." http:/ /www.demographia.com/db-nyc-ward1800.htm. Accessed January 3, 2013.

DiMaggio, Paul J. 1982. "Cultural Entrepreneurship in Nineteenth-Century Boston: The Creation of an Organizational Base for High Culture in America." Media, Culture and Society 4(4): 33-50.

----. 1988. "Interest and Agency in Institutional Theory." Pp. 3-21 in Institutional Patterns and Organizations, edited by Lynne G. Zucker. Cambridge, Mass.: Ballinger.

----. 1991. "Constructing an Organizational Field as a Professional Project: U.S. Art Museums, 19201940.” Pp. 267-92 in The New Institutionalism in Organizational Analysis, edited by Walter W. Powell and Paul J. DiMaggio. Chicago: University of Chicago Press.

Domosh, Mona. 1987. “Imagining New York's First Skyscrapers, 1875-1910.” Journal of Historical Geography 13:233-48.

Drayton, Richard. 2000. Nature's Government: Science, Imperial Britain, and the "Improvement" of the World. New Haven, Conn.: Yale University Press.

Duyckinck, Evert A. 1872. A Memorial of John David Wolfe. New York: New-York Historical Society. 
Eisenstadt, Shmuel N. 1964. "Social Change, Differentiation, and Evolution." American Sociological Review 29 (3): 375-86.

----. 1980. "Cultural Orientations, Institutional Entrepreneurs, and Social Change: Comparative

Analysis of Traditional Civilizations.” American Journal of Sociology 85 (4): 840-69.

Ewan, Joseph, and Nesta Dunn Ewan. 2007. Benjamin Smith Barton: Naturalist and Physician in Jeffersonian America. St. Louis: Missouri Botanical Garden Press.

Fligstein, Neil. 1997. "Social Skill and Institutional Theory." American Behavioral Scientist 40 (4): 397-405.

----. 2001. "Social Skill and the Theory of Fields." Sociological Theory 19 (2): 105-25.

Fligstein, Neil, and Doug McAdam. 2012. A Theory of Fields. Oxford: Oxford University Press.

Fontana, Walter. 2006. “The Topology of the Possible.” Pp. 67-84 in Understanding Change: Models, Methodologies, and Metaphors, edited by Andreas Wimmer and Reinhart Kössler. New York: Palgrave Macmillan.

Fourcade, Marion. 2011. "Cents and Sensibility: Economic Valuation and the Nature of 'Nature." American Journal of Sociology 116 (6): 1721-77.

Ganz, Marshall. 2000. "Resources and Resourcefulness: Strategic Capacity in the Unionization of California Agriculture, 1959-1966.” American Journal of Sociology 105 (4): 1003-62.

Gartner, Scott Sigmund, Michael R. Haines, Alan L. Olmstead, Richard Sutch, and Gavin Wright. 2006. "Table Bc568-587: Degrees Conferred by Institutions of Higher Education, by Degree and Sex." Historical Statistics of the United States, edited by Susan B. Carter. New York: Cambridge University Press, 2006.

Gleason, Henry A. 1960. "The Scientific Work of Nathaniel Lord Britton." Proceedings of the American Philosophical Society 104 (2): 205-26.

Greve, Henrich R., and Hayagreeva Rao. 2012. "Echoes of the Past: Organizational Foundings as Sources of an Institutional Legacy of Mutualism." American Journal of Sociology 118 (3): 635-75.

Grove, Carol. 2005. Henry Shaw's Victorian Landscapes: The Missouri Botanical Garden and Tower Grove Park. Amherst: Library of American Landscape History.

Hannan, Michael T. 2005. "Ecologies of Organizations: Diversity and Identity." Journal of Economic Perspectives 19 (1): 51-70.

Hannan, Michael T., and John Freeman. 1977. "The Population Ecology of Organizations." American Journal of Sociology 82 (5): 929-64.

----. 1984. "Structural Inertia and Organizational Change." American Sociological Review 49 (2): 149-64.

----. 1986. "Where Do Organizational Forms Come From?” Sociological Forum 1 (1): 50-72.

Harvard University. 1846. Rules and Statutes of the Professorships in the University at Cambridge. Cambridge, Mass.: Metcalf and Company.

Haveman, Heather A., and Hayagreeva Rao. 2006. "Hybrid Forms and the Organization of Thrifts." American Behavioral Scientist 49 (7): 974-86.

Hosack, Alexander Eddy. 1861. “A Memoir of the Late David Hosack, M.D.” Pp. 289-337 in Lives of Eminent American Physicians and Surgeons of the 19th Century, edited by Samuel D. Gross. Philadelphia: Lindsay \& Blakiston.

Hosack, David. 1803. "Botanic Garden." The Evening Post, June 29, 2.

----. 1806. Hortus Elginensis. New York: T. \& J. Swords.

----. 1810. "Description of Elgin Garden.” Portfolio and Boston Anthology, January 1810.

----. 1811. A statement of facts relative to the establishment and progress of the Elgin Botanic Garden, and the subsequent disposal of the same to the state of New-York. New York: C. S. Van Winkle. 
-----. 1828. "From Dr. Hosack to Mr. Rush.” The New-York Farmer and Horticultural Repository 1:39.

Howe, Marshall A. 1934. "Nathaniel Lord Britton, 1859-1934." Journal of the New York Botanical Garden 35 (416): 169-80.

Hsu, Greta, and Michael T. Hannan. 2005. "Identities, Genres, and Organizational Forms.” Organization Science 16 (5): 474-490.

James, Edward J. 1910. “The Origin of the Land-Grant Act.” University of Illinois University Studies 4 (1): 7 32.

Johnson, Victoria. 2007. "What Is Organizational Imprinting? Cultural Entrepreneurship in the Founding of the Paris Opera." American Journal of Sociology 113 (1): 97-127.

-----. 2012. "Identity, Sustainability, and Local Setting at U.S. Botanical Gardens.” Organization \& Environment 25 (3): 259-85.

Katznelson, Ira. 2003. "Periodization and Preferences." Pp. 270-301 in Comparative Historical Analysis in the Social Sciences, edited by James Mahoney and Dietrich Rueschemeyer. Cambridge: Cambridge University Press.

Kolodin, Irving. 1966. The Metropolitan Opera, 1883-1966. New York: Knopf.

Lagemann, Ellen Condliffe. 1989. The Politics of Knowledge: The Carnegie Corporation, Philanthropy, and Public Policy. Chicago: University of Chicago Press.

Lawrence, Thomas B., Roy Suddaby, and Bernard Leca. 2009. "Introduction: Theorizing and Studying Institutional Work.” Pp. 1-27 in Institutional Work: Actors and Agency in Institutional Studies of Organizations, edited by Thomas B. Lawrence, Roy Suddaby, and Bernard Leca. Cambridge: Cambridge University Press.

-----. 2011. "Institutional Work: Refocusing Institutional Studies of Organization.” Journal of Management Inquiry 20:52-58.

Leblebici, Huseyin, Gerald R. Salancik, Anne Copay, and Tom King. 1991. "Institutional Change and the Transformation of Interorganizational Fields: An Organizational History of the U.S. Radio Broadcasting Industry." Administrative Science Quarterly 36 (3): 333-63.

Mahoney, James. 2010. Colonialism and Postcolonial Development: Spanish America in Comparative Perspective. Cambridge: Cambridge University Press.

Mahoney, James, and Kathleen Thelen, eds. 2010. Explaining Institutional Change: Ambiguity, Agency, and Power. New York: Cambridge University Press.

McAdam, Doug. 1989. “The Biographical Consequences of Activism.” American Sociological Review 54 (5): 744-60.

McAdam, Doug, and Hilary Schaffer Boudet. 2012. Putting Social Movements in their Place. Cambridge: Cambridge University Press.

McAdam, Doug, John D. McCarthy, and Mayer N. Zald. 1996. "Introduction: Opportunities, Mobilizing Structures, and Framing Processes." Pp. 1-22 in Comparative Perspectives on Social Movements, edited by Doug McAdam, John D. McCarthy, and Mayer N. Zald. Cambridge: Cambridge University Press.

McCaughey, Robert A. 2003. Stand, Columbia: A History of Columbia University in the City of New York, 1754 2004. New York: Columbia University Press.

Merrill, Elmer D. 1938. "Biographical Memoir of Nathaniel Lord Britton, 1859-1934." National Academy of Sciences Biographical Memoirs 19 (1938): 147-202.

Mickulas, Peter. 2007. Britton's Botanical Empire: The New York Botanical Garden and American Botany, 1888 1929. New York: The New York Botanical Garden Press. 
Mora, G. Cristina. 2014. "Cross-Field Effects and Ethnic Classification: The Institutionalization of Hispanic Panethnicity, 1965 to 1990.” American Sociological Review 29 (2): 183-210.

Mukerji, Chandra. 1997. Territorial Ambitions and the Gardens of Versailles. Cambridge: Cambridge University Press.

-----. 2009. Impossible Engineering: Technology and Territoriality on the Canal du Midi. Princeton, N.J.: Princeton University Press.

Mullaly, John. 1887. The New Parks beyond the Harlem. New York: Record \& Guide.

Neem, Johann N. 2008. Creating a Nation of Joiners: Democracy and Civil Society in Early National Massachusetts. Cambridge, Mass.: Harvard University Press.

New York Academy of Sciences. 1935. "Nathaniel Lord Britton.” Science 81 (2091): 87-8.

New York Botanical Garden. 1896. "Agreement with Columbia University." Bulletin of the New York Botanical Garden 1 (1): 19-20.

New York State. 1891. "An act to provide for the establishment of a botanic garden and museum and arboretum, in Bronx park in the City of New York." In Laws of the State of New York, 523-25. Albany, N.Y.: Banks \& Brothers.

New-York State Society for the Promotion of Agriculture, Arts, and Manufactures. 1801. Transactions, vol. 1. 2nd ed. Albany, N.Y.: Charles R. and George Webster.

Orlikowski, Wanda. 2010. "The Sociomateriality of Organizational Life: Considering Technology in Management Research." Cambridge Journal of Economics 34:125-41.

Padgett, John F., and Christopher K. Ansell. 1993. "Robust Action and the Rise of the Medici, 14001434.” American Journal of Sociology 98 (6): 1259-1319.

Padgett, John F., and Paul D. McLean. 2006. "Organizational Invention and Elite Transformation: The Birth of Partnership Systems in Renaissance Florence." American Journal of Sociology 111 (5): 14631568.

Padgett, John F., and Walter W. Powell. 2012. The Emergence of Organizations and Markets. Princeton, N.J.: Princeton University Press.

Peterson, Richard A. 1986. "From Impresario to Arts Administrator: Formal Accountability in Nonprofit Arts Organizations." Pp. 161-183 in Nonprofit Enterprise in the Arts: Studies in Mission and Constraint, edited by Paul J. DiMaggio. Oxford: Oxford University Press.

Pierson, George W. 1983. Yale Book of Numbers: Historical Statistics of the College and University, 1701-1976. New Haven: Yale University Press.

Pólos, Lázslo, Michael T. Hannan, and Glenn R. Carroll. 2002. "Foundations of a Theory of Social Forms." Industrial and Corporate Change 11 (1): 85-115.

Powell, Walter W., and Jason Owen-Smith. 2012. “An Open Elite: Arbiters, Catalysts, or Gatekeepers in the Dynamics of Industry Evolution?” Pp. 466-495 in The Emergence of Organizations and Markets, John F. Padgett and Walter W. Powell. Princeton, N.J.: Princeton University Press.

Powell, Walter W., Kelley Packalen, and Kjersten Whittington. 2012. "Organizational and Institutional Genesis: The Emergence of High-Tech Clusters in the Life Sciences.” Pp. 434-65 in The Emergence of Organizations and Markets, edited by John F. Padgett and Walter W. Powell. Princeton, N.J.: Princeton University Press.

Powell, Walter W., and Kurt W. Sandholtz. 2012. "Amphibious Entrepreneurs and the Emergence of Organizational Forms.” Strategic Entrepreneurship Journal 6 (2): 94-115.

Rao, Hayagreeva, Calvin Morrill, and Mayer N. Zald. 2000. "Power Plays: How Social Movements and Collective Action Create New Organizational Forms." Research in Organizational Behavior 22:23782. 
Rao, Hayagreeva, Philippe Monin, and Rodolphe Durand. 2003. "Institutional Change in Toque Ville: Nouvelle Cuisine as an Identity Movement in French Gastronomy." American Journal of Sociology 108 (4): 795-843.

Robbins, Christine Chapman. 1964. David Hosack: Citizen of New York. Philadelphia: American Philosophical Society.

Romayne, Nicholas. 1811. "Anniversary Address to the Medical Society of the State of New York by the President Nicholas Romayne.” New York Medical \& Surgical Journal 2:123.

Rosenzweig, Roy, and Elizabeth Blackmar. 1992. The Park and the People. Ithaca: Cornell University Press. Rudolph, Emanuel D. 1996. "History of the Botanical Teaching Laboratory in the United States." American Journal of Botany 83 (5): 661-71.

Ruef, Martin. 2000. "The Emergence of Organizational Forms: A Community Ecology Approach." American Journal of Sociology 106 (3): 658-714.

Rusby, Henry Hurd. 1934. “Nathaniel Lord Britton.” Science 80 (2066): 108-11.

Schneiberg, Marc. 2007. "What's on the Path? Path Dependence, Organizational Diversity, and Institutional Change in the U.S. Economy, 1900-50.” Socio-Economic Review 5:47-80.

Scobey, David M. 2002. Empire City: The Making and Meaning of the New York City Landscape. Philadelphia: Temple University Press.

Scott, Anne Firor. 1993. Natural Allies: Women's Associations in American History. Champaign: University of Illinois Press.

Scott, Eleanor Bryce. 1933. "Early Literary Clubs in New York City." American Literature 5 (1): 3-16. Sewell, William H., Jr. 2005. “Theory, History, and Social Science.” Pp. 1-21 in William H. Sewell, Jr., Logics of History: Social Theory and Social Transformation. Chicago: University of Chicago Press.

Sharkey, Amanda J. 2014. "Categories and Organizational Status: The Role of Industry Status in the Response to Organizational Deviance.” American Journal of Sociology 119 (5): 1380-1433.

Sheingate, Adam D. 2003. "Political Entrepreneurship, Institutional Change, and American Political Development." Studies in American Political Development 17:185-203.

Sloan, Douglas. 1980. "Science in New York City, 1867-1907." Isis 71 (256): 35-76.

Smith, Edward Bishop. 2011. "Identities as Lenses: How Organizational Identity Affects Audiences' Evaluation of Organizational Performance.” Administrative Science Quarterly 56:61-94.

Stark, David. 2009. A Sense of Dissonance. Princeton, N.J.: Princeton University Press.

Stinchcombe, Arthur L. 1965. "Social Structure and Organizations." Pp. 142-193 in Handbook of

Organizations, edited by James G. March. New York: Rand McNally.

-----. 1968. Constructing Social Theories. New York: Harcourt Brace.

Svenson, Henry K. 1944. “C. Stuart Gager (1873-1943).” Ecology 25 (1): 1-2.

Taylor, Alan. 2012. The Civil War of 1812. New York: Vintage.

Taylor, Dorceta E. 2009. The Environment and the People in American Cities, 1600s-1900s: Disorder, Inequality, and Social Change. Durham, N.C.: Duke University Press.

Thelen, Kathleen. 2004. How Institutions Evolve. New York: Cambridge University Press.

Torrey Botanical Club. 1889. “Appeal for a Public Botanic Garden in New York City.” Mertz Library, New York Botanical Garden.

Tye, Michael. 2000. Consciousness, Color, and Content. Cambridge, Mass.: MIT Press.

Vail, Robert W. G. 1954. Knickerbocker Birthday: A Sesqui-Centennial History of the New-York Historical Society, 1804-1954. New York: New-York Historical Society. 
Vedres, Balázs, and David Stark. 2010. "Structural Folds: Generative Disruption in Overlapping Groups.” American Journal of Sociology 115 (4): 1150-90.

Wagner, Andreas. 2005. Robustness and Evolvability in Living Systems. Princeton, N.J.: Princeton University Press.

Walker, Edward T., Andrew W. Martin, and John D. McCarthy. 2008. "Confronting the State, the Corporation, and the Academy: The Influence of Institutional Targets on Social Movement Repertoires." American Journal of Sociology 114 (1): 35-76.

Wulf, Andrea. 2008. The Brother Gardeners. New York: Vintage.

Wuthnow, Robert. 1989. Communities of Discourse. Cambridge, Mass.: Harvard University Press.

Zunz, Olivier. 2014. Philanthropy in America: A History. Princeton, N.J.: Princeton University Press. 
TABLE 1

COMPARATIVE SUMMARY OF CASES

\begin{tabular}{|c|c|c|}
\hline & David Hosack & Nathaniel Britton \\
\hline Project & $\begin{array}{l}\text { Botanical garden needed for teaching } \\
\text { and research }\end{array}$ & $\begin{array}{l}\text { Botanical garden needed for teaching } \\
\text { and research }\end{array}$ \\
\hline \multirow[t]{3}{*}{ Biography } & Columbia College training & Columbia University training \\
\hline & $\begin{array}{l}\text { Columbia professor of medicine and } \\
\text { botany }\end{array}$ & Columbia professor of botany \\
\hline & $\begin{array}{l}\text { Close personal relations with } \\
\text { prominent doctors, lawyers, and } \\
\text { politicians in New York, Philadelphia, } \\
\text { and Washington, D.C. }\end{array}$ & $\begin{array}{l}\text { Professional affiliations with } \\
\text { prominent New York scientists and } \\
\text { industrialists }\end{array}$ \\
\hline Template & $\begin{array}{l}\text { Early 19th-century British botanical } \\
\text { gardens }\end{array}$ & $\begin{array}{l}\text { Late 19th-century British botanical } \\
\text { gardens }\end{array}$ \\
\hline \multirow[t]{2}{*}{ Social skill } & $\begin{array}{l}\text { Articulation of benefit to city's and } \\
\text { country's medical and agricultural } \\
\text { progress }\end{array}$ & $\begin{array}{l}\text { Articulation of benefit to city's and } \\
\text { country's botanical, medical, } \\
\text { agricultural, and aesthetic progress }\end{array}$ \\
\hline & $\begin{array}{l}\text { Binding of project to Columbia } \\
\text { College, State of New York, and New } \\
\text { York City elites }\end{array}$ & $\begin{array}{l}\text { Binding of project to Columbia } \\
\text { University, State of New York, and } \\
\text { New York City elites }\end{array}$ \\
\hline
\end{tabular}


TABLE 2

Changes in the Material EnVIRONMENT OF 19Th-CENTURy NeW YORK CiTy

\begin{tabular}{lll}
\hline \hline & \multicolumn{1}{c}{ Early Republic } & \multicolumn{1}{c}{ Gilded Age } \\
\hline New York City population ${ }^{22}$ & In 1800: 60,500 & In 1900: 1,850,000 \\
$\begin{array}{c}\text { Avg. pop. per square mile } \\
\text { Northern border of New } \\
\text { York City }\end{array}$ & In 1800: 3,000 1800: Houston Street ${ }^{24}$ & In 1900: 90,400 \\
$\begin{array}{c}\text { Intural/built composition of } 207^{\text {th }} \text { Street }^{25} \\
\text { Manhattan Island }\end{array}$ & $\begin{array}{l}\text { In 1800, Manhattan is largely } \\
\text { farmland and country } \\
\text { estates. }\end{array}$ & $\begin{array}{l}\text { Manhattan is largely built } \\
\text { over except for Central Park } \\
\text { and Inwood section of } \\
\text { northern Manhattan }\end{array}$ \\
& & $\begin{array}{l}\text { New } \text { the } \\
\text { is found Park Association }\end{array}$ \\
& &
\end{tabular}

22 “New York (Manhattan) Wards: Population \& Density 1800-1910," http:/ /www.demographia.com/db-nycward1800.htm, accessed January 3, 2013.

${ }^{23}$ Ibid.

24 Taylor, Benjamin, and John Roberts, Taylor-Roberts Plan, 1797. In Manhattan in Maps: 1527-1995, by Paul E. Cohen and Robert T. Augustyn, New York: Rizzoli, 1997: 94-5.

25 White, Jeremy, Matthew Ericson, Ford Fessenden, Micah Cohen, Joe Burgess, and Archie Tse, "How Manhattan's Grid Grew," New York Times, March 20, 2011, accessed January 3, 2013.

http://www.nytimes.com/interactive/2011/03/21/nyregion/map-of-how-manhattan-grid-grew.html.

26 Burrows and Wallace 1999; quoted in Sanderson and Brown 2007: 549.

27 New York Times, November 27, 1881, p. 14 
TABLE 3

Changes in Civic Organization In 19TH-CENTURy NeW York City

\begin{tabular}{|c|c|c|}
\hline & Early Republic & Gilded Age \\
\hline $\begin{array}{l}\text { Primary organizational type } \\
\text { in arts and sciences }\end{array}$ & $\begin{array}{l}\text { Member-serving societies, } \\
\text { funded by participants }\end{array}$ & $\begin{array}{l}\text { Public-serving institutions, } \\
\text { funded by patronage }\end{array}$ \\
\hline Organizational goals & $\begin{array}{l}\text { Education and refinement of } \\
\text { members; general elevation } \\
\text { of New York City and the } \\
\text { young United States }\end{array}$ & $\begin{array}{l}\text { Education and refinement of } \\
\text { New York City citizens; } \\
\text { general elevation of New } \\
\text { York City }\end{array}$ \\
\hline Organizational structure & $\begin{array}{l}\text { Subscription-based } \\
\text { (managers, funders, and } \\
\text { beneficiaries same people) }\end{array}$ & $\begin{array}{l}\text { Expert managers } \\
\text { (managers distinct from } \\
\text { funders; beneficiaries include } \\
\text { both but also broader public) }\end{array}$ \\
\hline Examples & $\begin{array}{l}\text { Society for the Promotion of } \\
\text { Agriculture, Arts, and } \\
\text { Manufactures (1792), New- } \\
\text { York Historical Society } \\
\text { (1804), Literary and } \\
\text { Philosophical Society (1814) }\end{array}$ & $\begin{array}{l}\text { Metropolitan Museum of Art } \\
\text { (1870), American Museum of } \\
\text { Natural History (1874), } \\
\text { Metropolitan Opera (1883), } \\
\text { New York Public Library } \\
\text { (1895) }\end{array}$ \\
\hline
\end{tabular}


TABLE 4

CHANGES In THE ORgANiZATION OF EXPERT KNOWLEDGE IN THE 19TH CENTURY

\section{Early Republic}

Gilded Age

Botanical collection and research conducted primarily by American professional botanists employed by research institutes and universities primarily by European botanists working on behalf of European botanical gardens and universities, and by American "gentlemen" as a non-professional pursuit

Professorships of botany (Columbia, College of Philadelphia, Yale); no departments

No local or national associations dedicated to botany

Composed of an arts faculty and a college of medicine; no graduate schools

In 1800, 70 students were enrolled in Columbia; $14 \%$ medical students and $86 \%$ arts students. $^{29}$

In 1800, 16 students graduated (no medical students). ${ }^{30}$
Departments of botany across the United States (Columbia University, Harvard University, University of Chicago, University of Michigan)

New York City: Torrey Botanical Club (founded 1860s)

National: Botanical Society of America (1893), organized as a division of American Association for the Advancement of Science

In 1893, composed of: Columbia College; Law School; School of Mines; School of Architecture; School of Medicine; Faculty of Political Science; Faculty of Philosophy; Faculty of Pure Science ${ }^{28}$

In 1900,3340 students were enrolled. ${ }^{31}$

In 1900, 542 students graduated, including:

97 College,

88 Law,

59 School of Mines,

16 School of Architecture,

158 School of Medicine,

104 Masters degrees (various fields),

$20 \mathrm{PhDs}$ (various). ${ }^{32}$

Britton:

Torrey Botanical Club; Natural Science Association of Staten Island; American Association for the Advancement of Science; Scientific Alliance of New York; Botanical Society of America

${ }^{28}$ http://beatl.barnard.columbia.edu/stand_columbia/TimelineECU.htm. Accessed January 3, 2013.

${ }^{29} \mathrm{http}: / /$ beatl.barnard.columbia.edu/stand_columbia/Appendix\%20B/stud-schoolenroll1800.html. Accessed January 3, 2013.

30 http://beatl.barnard.columbia.edu/stand_columbia/TimelineECC.htm. Accessed January 3, 2013.

${ }^{31} \mathrm{http}: / /$ beatl.barnard.columbia.edu/stand_columbia/Appendix\%20B/stud-enroll1900-1950.html. Accessed January 3, 2013.

32http://beatl.barnard.columbia.edu/stand_columbia/Appendix $\% 20 \mathrm{~B} /$ Early $\% 20$ Columbia $\% 20$ University $\% 20 \mathrm{G}$ raduates.htm. Accessed January 3, 2013. 
TABLE 5

IMPACT OF MACRO-LEVEL SHIFTS ON MESO- AND MICRO-LEVEL PROCESSES

\begin{tabular}{|c|c|c|c|c|}
\hline \multirow[b]{2}{*}{$\begin{array}{l}\text { Macro-level (regional, } \\
\text { national) shifts }\end{array}$} & \multicolumn{2}{|c|}{ Early Republic } & \multicolumn{2}{|c|}{ Gilded Age } \\
\hline & $\begin{array}{l}\text { Impact on meso-level } \\
\text { (organizational) }\end{array}$ & $\begin{array}{l}\text { Impact on micro-level } \\
\text { (individual) }\end{array}$ & $\begin{array}{l}\text { Impact on meso-level } \\
\text { (organizational) }\end{array}$ & $\begin{array}{l}\text { Impact on micro-level } \\
\text { (individual) }\end{array}$ \\
\hline Material environment & $\begin{array}{l}\text { Availability of land } \\
\text { means no urgency re: } \\
\text { preservation and } \\
\text { beautification. }\end{array}$ & $\begin{array}{l}\text { Hosack does not } \\
\text { appeal to (or think } \\
\text { of) preservation or } \\
\text { beautification. }\end{array}$ & $\begin{array}{l}\text { High urbanization } \\
\text { gives rise to parks } \\
\text { movement, } \\
\text { mobilizing network } \\
\text { of concerned elites. }\end{array}$ & $\begin{array}{l}\text { Preservation and } \\
\text { beautification of } \\
\text { green space are } \\
\text { salient arguments } \\
\text { to which Britton } \\
\text { can appeal. }\end{array}$ \\
\hline Civic organization & $\begin{array}{l}\text { Two organizational } \\
\text { models: member- } \\
\text { serving and serving- } \\
\text { the-needy; a } \\
\text { botanical garden fit } \\
\text { neither model. }\end{array}$ & $\begin{array}{l}\text { Hosack has no } \\
\text { natural } \\
\text { constituency to } \\
\text { mobilize; elites } \\
\text { who praise garden } \\
\text { are not direct } \\
\text { beneficiaries and } \\
\text { don't fund it; the } \\
\text { most direct } \\
\text { beneficiaries } \\
\text { (medical students } \\
\text { and farmers) are } \\
\text { not in a position to } \\
\text { fund it. }\end{array}$ & $\begin{array}{l}\text { Rise in private } \\
\text { fortunes, social } \\
\text { climbing, social } \\
\text { problems, and } \\
\text { social gospel give } \\
\text { life by } 1880 \text { s to } \\
\text { models of private- } \\
\text { public } \\
\text { collaboration, such } \\
\text { as the Metropolitan } \\
\text { Museum of Art and } \\
\text { the American } \\
\text { Museum of Natural } \\
\text { History. }\end{array}$ & $\begin{array}{l}\text { Britton profits } \\
\text { from the } \\
\text { familiarity of NYC } \\
\text { citizens with these } \\
\text { organizational } \\
\text { templates and past } \\
\text { civic successes. }\end{array}$ \\
\hline $\begin{array}{l}\text { Organization of } \\
\text { expert } \\
\text { knowledge }\end{array}$ & $\begin{array}{l}\text { Elites are polymaths, } \\
\text { but botany is not } \\
\text { part of requisite } \\
\text { education of a } \\
\text { gentleman, as is } \\
\text { learning in history } \\
\text { and visual arts; hence } \\
\text { the founding of the } \\
\text { Historical Society } \\
\text { and the Academy of } \\
\text { Fine Arts, but not an } \\
\text { Academy of Botany, } \\
\text { and no private-elite } \\
\text { funding for a } \\
\text { botanical garden. }\end{array}$ & $\begin{array}{l}\text { Hosack cannot } \\
\text { mobilize private } \\
\text { support for a } \\
\text { specialist-training } \\
\text { organization. }\end{array}$ & $\begin{array}{l}\text { Rise in trust of } \\
\text { experts in business, } \\
\text { culture, and science } \\
\text { meant familiarity of } \\
\text { potential private } \\
\text { funders with } \\
\text { managerial model; } \\
\text { establishment of } \\
\text { department of } \\
\text { botany at Columbia } \\
\text { both signified and } \\
\text { reinforced new } \\
\text { status of botany as a } \\
\text { science. }\end{array}$ & $\begin{array}{l}\text { Britton can argue } \\
\text { that botany as a } \\
\text { science merits its } \\
\text { own organization; } \\
\text { he can also } \\
\text { mobilize support } \\
\text { for himself as } \\
\text { expert. }\end{array}$ \\
\hline
\end{tabular}




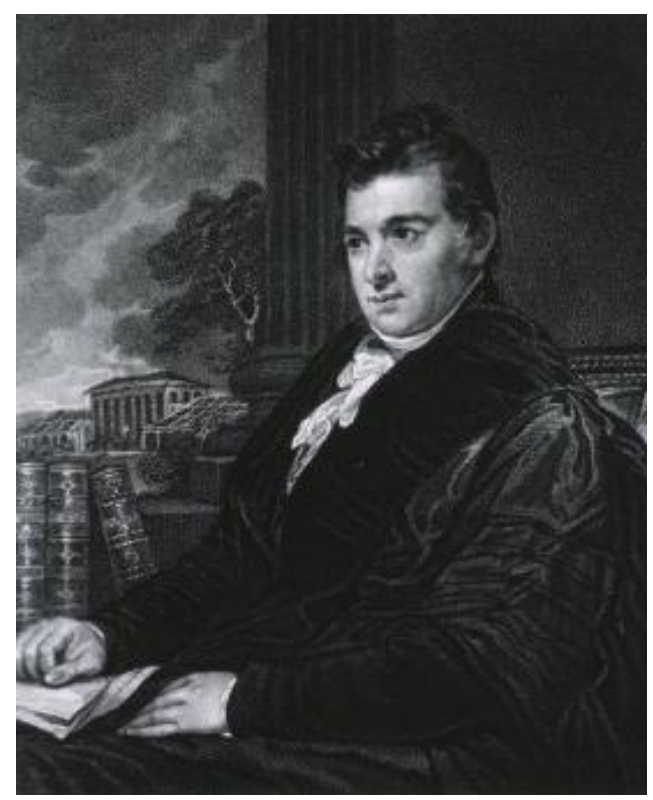

FIG. 1.-David Hosack. Source: Charles Heath. David Hosack, M.D., F.R.S., n.d. Engraving after painting by Thomas Sully. U.S. National Library of Medicine, Images from the History of Medicine. http://ihm.nlm.nih.gov/luna/servlet/view/search?q=B015184. Accessed January 3, 2013.

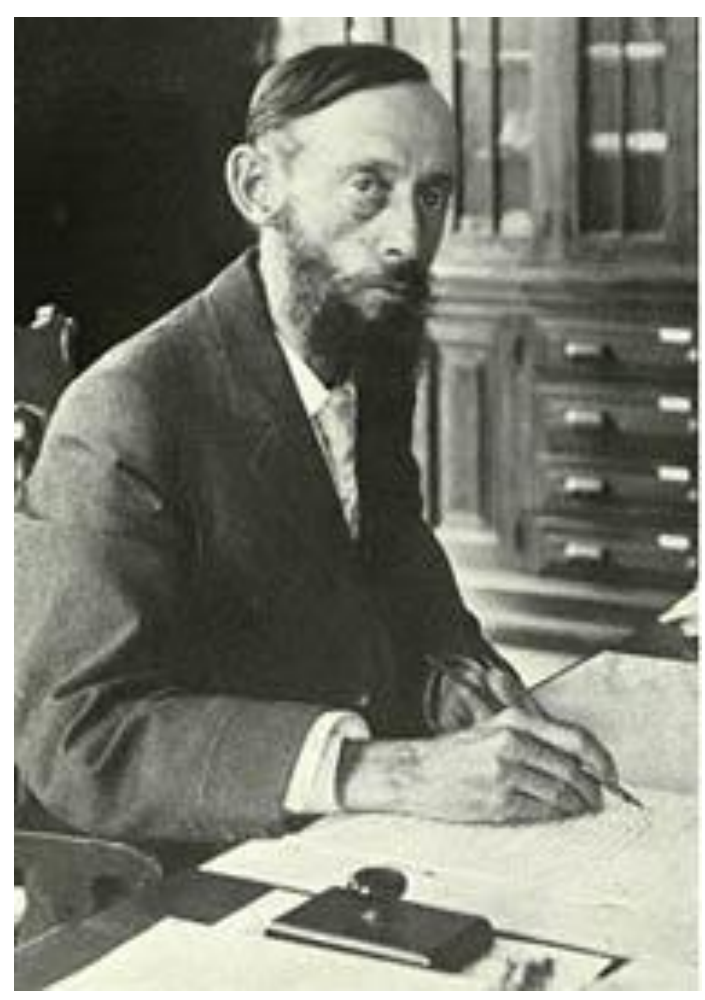

FIG. 2.-Nathaniel Britton. Source: Mertz Library, New York Botanical Garden. http://sciweb.nybg.org/science2/libr/finding_guide/britwb2.asp.html. Accessed January 3, 2013. 


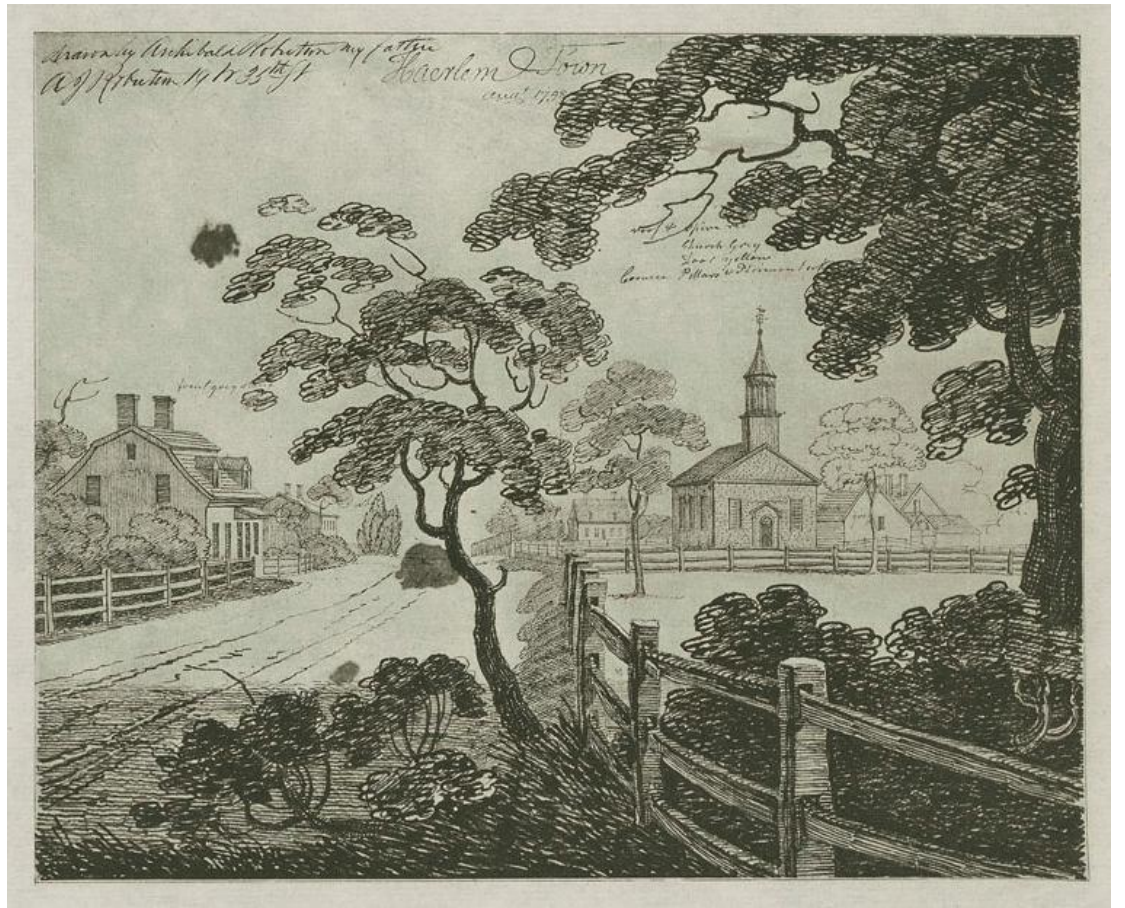

FIG. 3.- Town of Haerlem (Harlem), northern Manhattan, in 1798. Source: Plate 60b in I. N. Phelps Stokes, The iconography of Manhattan Island, 1498-1909, v. 1. New York: Robert H. Dodd, 1915-1928.

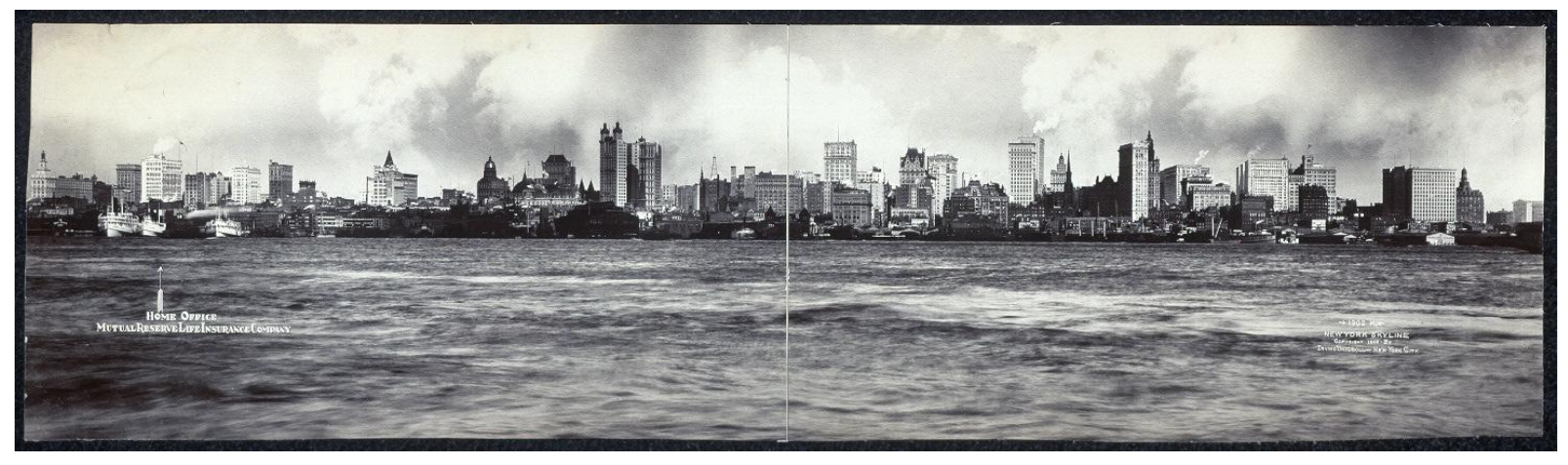

FIG. 4.-Manhattan skyline in 1902. Source: Irving Underhill, 1902 M, New York skyline, Library of Congress Prints and Photographs Online Catalog. Lot 12475, no. 13 (OSF) [P\&P]. http://www.loc.gov/pictures/item/2007662377/. Accessed January 3, 2013. 


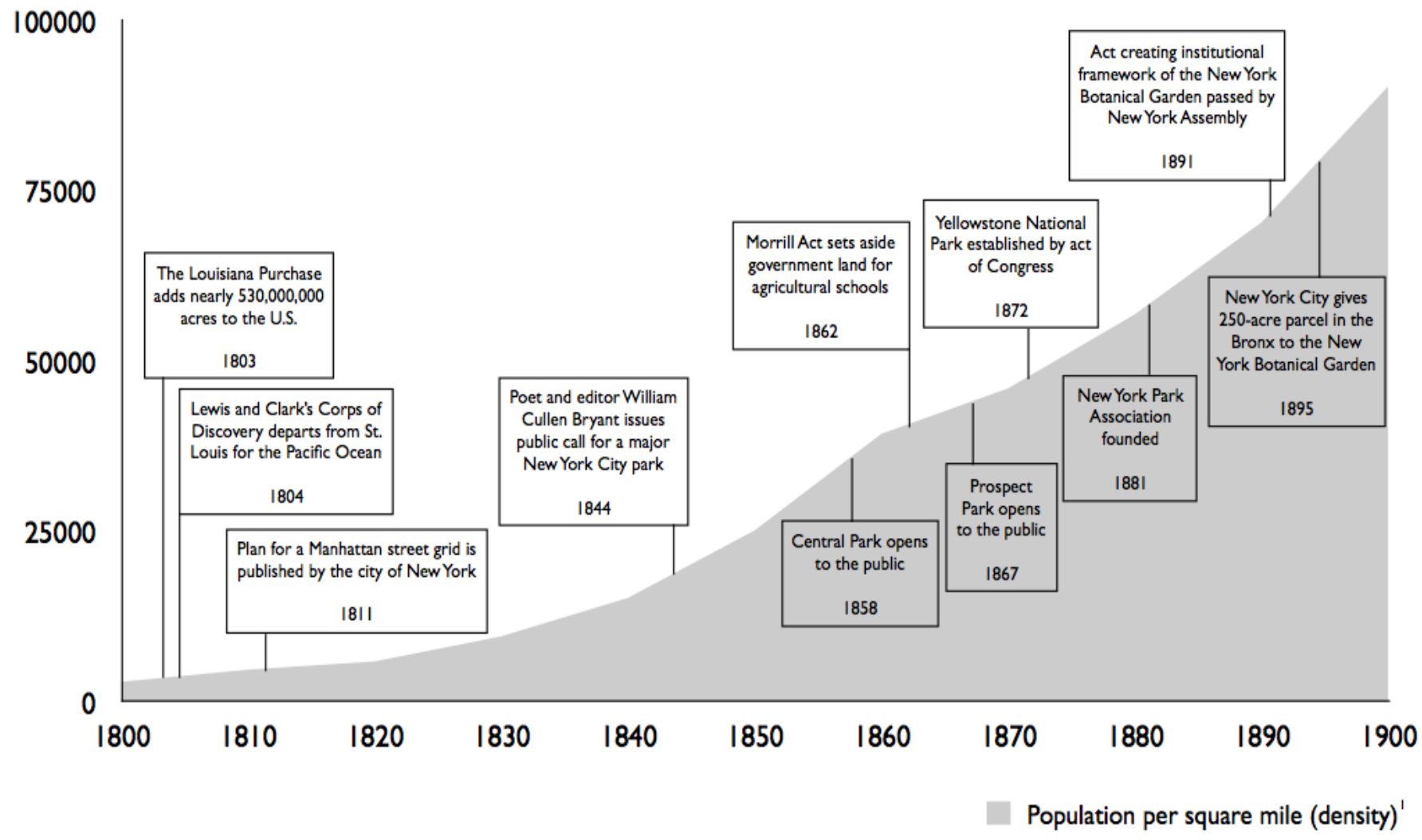

' "New York (Manhattan) Wards: Population \& Density 1800-1910." (2001). Demogrophio. http://www.demographia.com/db-nyc-ward/800.htm.

FIG. 5.- Transformation of material environment in 19th-century New York City and U.S. 


\section{0}

15

10

New York Academy of the Fine Arts founded

0

1800

\section{2}

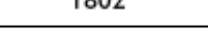

5
New-York Literary and New York Female Moral

Free School Philosophical

founded $\quad \begin{gathered}\text { Society } \\ \text { founded }\end{gathered}$

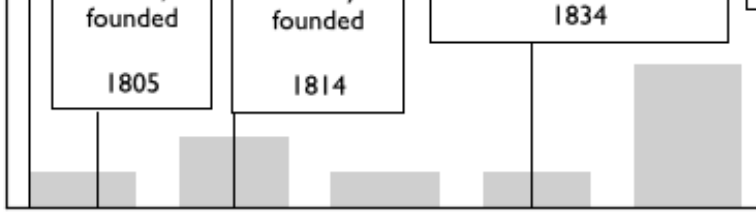
Reform Society founded
American Museum of Natural History founded

1874
New York Public

Library created

out of a merger of the Astor and

Lenox Libraries

1895

Metropolitan

Opera founded

1883

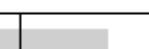

John D. Rockefeller creates the General Education Board

1902

Margaret Olivia

Sloçum Sage creates the

Russell Sage

Foundation

1907

FIG. 6.-Transformation of associational life in 19th-century New York City and U.S. 


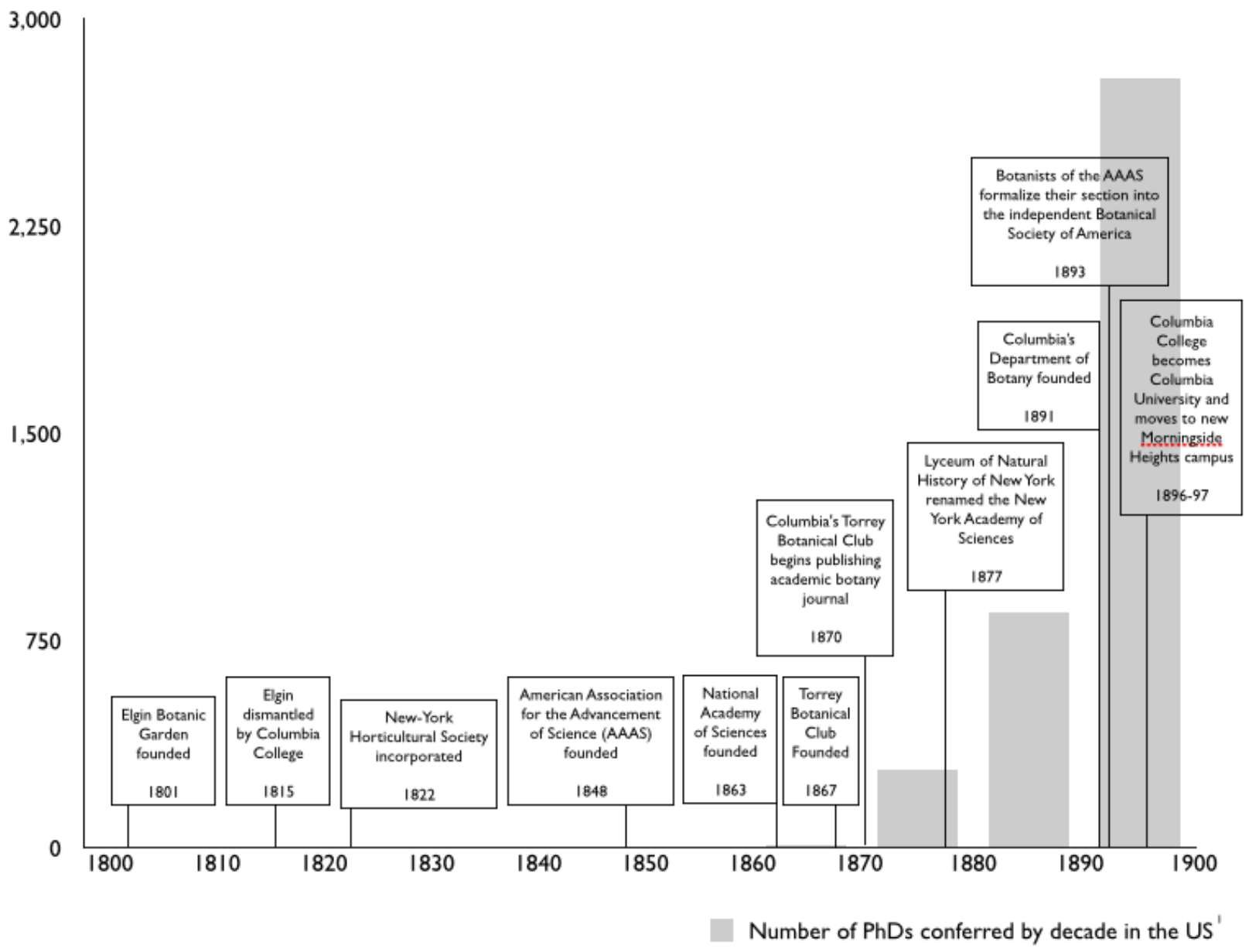

'Scott Sigmund Gartner, Michael R. Haines, Alan L. OImstead, Richard Sutsb, and Gavin Wright. "Degrees Conferred by Institutions of Higher Education, by Degree and Sex," Table Bc568-587. Historical statistics of the United States. Edited by Susan B. Carter. New York: Cambridge University Press, 2006.

FIG. 7.- Transformation of science and botany in 19th-century New York City and U.S. 